\title{
Soil and Water Conservation Measures and Challenges in Kenya; a Review
}

\author{
George Njomo Karuku* \\ Department of Land Resource and Agricultural Technology, University of Nairobi, Kenya
}

Received: 眥 May 02, 2018; Published: 㘹 May 22, 2018

*Corresponding author: George Njomo Karuku, Department of Land Resource and Agricultural Technology, University of Nairobi, Kenya

\begin{abstract}
The preservation and sustainable development of soil and water resources is one of the basic principles for the development of Kenya. Throughout the course of history, all the social improvement and economic development are deeply concerned with soil loss and ecological environmental protection. Poor soil and water conservation measures will lead to land degradation that are either natural or human induced. Natural hazards include land topography and climatic factors such as steep slopes, landslides from frequent floods, blowing of high velocity winds, rains of high intensity, strong leaching in humid regions and drought conditions in the dry regions. It is now common sense that soil and water conservation is the insurance for national ecology and its development. Consequences to land degradation leads to increased use of inputs and greater costs where farmers attempt to combat reduction in yields with increased inputs, particularly fertilizers. For the past long period of time, soil and water loss has been recognized as number one killer to the ecological environment and Kenya is at critical conditions for its development with complicated geological conditions and accelerated human destruction and serious soil and water losses. Based on historical documents, experience and detailed data analysis, this paper aims to review the general characteristics of soil and water loss, to explore the relationship between soil and water conservation and sustainable economic development, and to provide relevant strategies for soil and water conservation in Kenya.
\end{abstract}

Keywords: Soil and water conservation; Conservation methods and techniques; Degradation; Challenges and opportunities

Abbreviations: EAC: East African Community; ASALs: Arid and Semi-Arid Lands; KFS: Kenya Forestry Services; UH: Upper highland; LH: lower highland; LM: Upper Midland; LM: Lower Midland; CL: Coastal Lowlands; SIDA: Swedish International Development Agency; MFC: Mau Forests Complex

\section{Introduction}

The Republic of Kenya is in Africa and a founding member of the East African Community (EAC) with the capital city Nairobi. Kenya's territory lies on the equator and overlies the East African Rift covering a diverse and expansive terrain that extends roughly from Lake Victoria to Lake Turkana (formerly Lake Rudolf) and further south-east to the Indian Ocean. It is bordered by Tanzania to the south and southwest, Uganda to the west, South Sudan to the north-west, and Ethiopia to the north and Somalia to the north-east. Kenya covers $581,309 \mathrm{~km}^{2}$, and current population of $50,410,740$ as of Saturday, January 27, 2018, based on the latest United Nations estimates, of which $74 \%$ lives in rural areas. Average population

density is 87 per $\mathrm{km}^{2}$, but its distribution is highly influenced by climate and agro-ecological zone. The highest density is found in western province. From 2002, the population growth rate was estimated at 1.85 per year. Life expectancy increased up to 60 years by 1993 but dropped to 45 years by 2002 due to high incidence of HIV/AIDS [1]. Overall, poverty level was estimated at $30.8 \%$ in 2004 . Improved water sources are accessible for $62 \%$ of the population, ranging from $89 \%$ in urban areas to $46 \%$ in rural areas. Improved sanitation facilities are used by $56 \%$ of the population in urban areas and $43 \%$ in rural areas, while average over the whole country is $48 \%$ AIDS [2]. 
Kenya has a warm and humid tropical climate on its Indian Ocean coastline and cooler in the savannah grasslands around the capital city, Nairobi, and especially closer to Mt Kenya, which has permanent snow on its peaks. Further in land are highlands in Central and Rift Valley regions where farmers grow tea and coffee as cash crops and are major foreign revenue earners. To the West are Nyanza and Western regions, with an equatorial, hot and dry climate which becomes humid around Lake Victoria, the largest tropical fresh-water lake in the world. This gives way to temperate and forested hilly areas in the neighbouring western region. The north-eastern regions along the border with Somalia and Ethiopia are arid and semi-arid lands (ASALs) with near-desert landscapes. Kenya is known for its world class long distance athletes in track and also field events and rugby. Its diverse climate and geography give rise to expansive wildlife reserves, national parks and white sandy beaches at the Coastal region making Kenya home to the modern safari. Kenya has several world heritage sites such as Lamu, Diani, Bamburi and Kilifi, where international yachting competitions are held every year as well as being the cradle of mankind in Lake Turkana where oldest fossils for early man were first discovered. The Kenya economy is the largest by GDP in East and Central Africa $[3,4]$. The capital, Nairobi is a regional commercial hub. Agriculture is a major employer with country's traditionally exports of tea, coffee and fresh flowers to Europe.

\section{Soil Types}

The soil types in the country vary from place to place due to topography, amount of rainfall and parent material. In western Kenya the soils are mainly; Acrisols, Cambisols [5] and their mixtures, are highly weathered, leached and with high accumulation of Iron and Aluminum oxides. The soils in Central Kenya and the highlands are mainly Nitisols and Andosols, are young and of volcanic origin. The arid and semi-arid lands (ASALs) comprise of Vertisols, Gleysols and Phaozems [5], and are characterized by pockets of sodicity and salinity, low fertility and are vulnerable to erosion. Coastal soils are coarse textured and low in organic matter; the most common type being Arenosols, Luvisols and Acrisols. Widespread soil salinity, which has adversely influenced irrigation development, is found in isolated pockets around Lake Baringo basin in the Rift Valley and in Taveta division of the coast region [2].

\section{Rainfall and agro-ecological zones}

Average annual rainfall is $630 \mathrm{~mm}$ with a variation from less than $200 \mathrm{~mm}$ in northern Kenya to $>1,800 \mathrm{~mm}$ on the slopes of Mt. Kenya. Rainfall distribution pattern is bimodal with long rains falling from March to May and short rains from October to November for most parts of the country. The climate is influenced by the Inter-tropical Convergence Zone and relief, and ranges from permanent snow above $4,600 \mathrm{~m}$ on Mt. Kenya to true desert type in the Chalbi desert in Marsabit district, north of the country. About $80 \%$ of the country is ASAL, while $17 \%$ is considered high potential agricultural land, sustaining $75 \%$ of population. Forest cover is about $3 \%$ of total land area. The country has six major agro-ecological zones namely: Upper highland (UH), lower highland (LH), upper midland (LM), lower midland (LM), lowland (L) and coastal lowlands (CL). These zones are associated with corresponding temperature variations ranging from freezing to $40 \mathrm{OC}$. The Penman estimate of annual evaporation from open water surfaces in Kenya varies from 1000mm in Central highlands to 2,600mm in arid north. According to [2], agricultural land covers $33 \%$ of the country and is classified as (i) high potential land receiving more than $850 \mathrm{~mm}$ of annual rainfall, $67,850 \mathrm{~km}^{2}$ (ii) medium potential land receiving $850-730 \mathrm{~mm}$; covering $31,570 \mathrm{~km}^{2}$ (iii) low potential land receiving less than $610 \mathrm{~mm}$, covering $42,050 \mathrm{~km}^{2}$ (iv) other lands covering $48,670 \mathrm{~km}^{2}$.

\section{Soil water conservation}

The United Nations predicts that 1.8 billion people will experience absolute water scarcity in less than 5 years, and worry that by 2025, two out of three persons will be living in waterstressed regions. Already every five persons worldwide cannot access their basic everyday water resource, a fact recently witnessed in Cape Town, South Africa which is in dire need of water with serious rationing of the commodity. Water may well be a renewable resource, but its capacity to renew itself depends on how it is managed. Man faces serious water management crisis according to the Pacific Institute book in its world water series [6]. Increasing efficiency in use and reducing wastage in water systems is quite often the cheapest, easiest way for us to get new water, something that is mostly ignored in future water planning programs the world over [7]. Poor management of resources such as unplanned land clearing for cultivation and deforestation of the water towers has led to serious environmental and ecological degradation as well as reduced water volumes. In Kenya, hiving of forest land for political expediency plus illegal invasion and settlements in large swathes of forests at Hombe and Timau in Mt Kenya, Ngong forest, Masaai Mara and Aberdare ranges among others has led to erratic and low rainfall experienced in the maize and wheat growing belts of Kenya as well as in the Game reserves and national parks where the rivers are drying up. The dwindling water resources as the rivers dry has led to migration of the famous flamingo birds from L. Nakuru hence affecting ecotourism in the bird sanctuary. The Masaai Mara Game Reserve that was once voted the seventh wonder of the world due to the wildebeest seasonal migration every year is experiencing challenges as the Mara river shrinks and the crocodiles and other wildlife unable to thrive and flourish. Some lakes like Kamnyarok in the same belt have dried up leaving a trial of death and devastation in their wake.

Kipsang [8] in an article in the standard newspaper bemoaned the human activity threatening important water towers in Kenya especially Kaptagat (Plate 1) that forms part of the Mau complex. On a national scale, accelerating deforestation, soil erosion and environmental degradation remain a major concern. Water resources are under pressure in parts of the country owing to overuse, not only for agricultural and domestic consumption but also for hydro-power and wildlife. Ecological disruption of inland 
lakes, particularly Lakes Victoria, Turkana and Naivasha, is a major concern for the fishing industry. Other inland lakes such as Lakes Baringo and Ol' Bolossat are equally devastated. For example L. Kamnyarok which has already dried up and unless something drastic is done, it will be extinct in the near future. The lake was the lifeline for many wild animals such as crocodiles, elephants, buffaloes and various birds. There was a time when some 15,000 crocodiles gathered in this lake but the rapid drying up of the lake have caused death to a large number as they tried to escape and find a new home elsewhere. The people of the region and its surrounding areas were fully dependent (plate 2) on this water source for various activities. The dying lake once got its recognition as a wetland throughout the world by the Ramsar Convention but is no more. The residents are now worried on how to continue with their farming activities and watering their livestock, a major challenge with the current draught ravaging many parts of Kenya. Many reasons being advanced on possible causes for the drying up of lake such as poor farming practices and gulley of Kiptilit resulting in acute sedimentation and indiscriminate cutting of trees were considered among the common factors responsible. It was though, decided that the lake would be restored but the fight between the Barwessa division's residents and the Baringo county council have so far disrupted the initiative (plate 3).

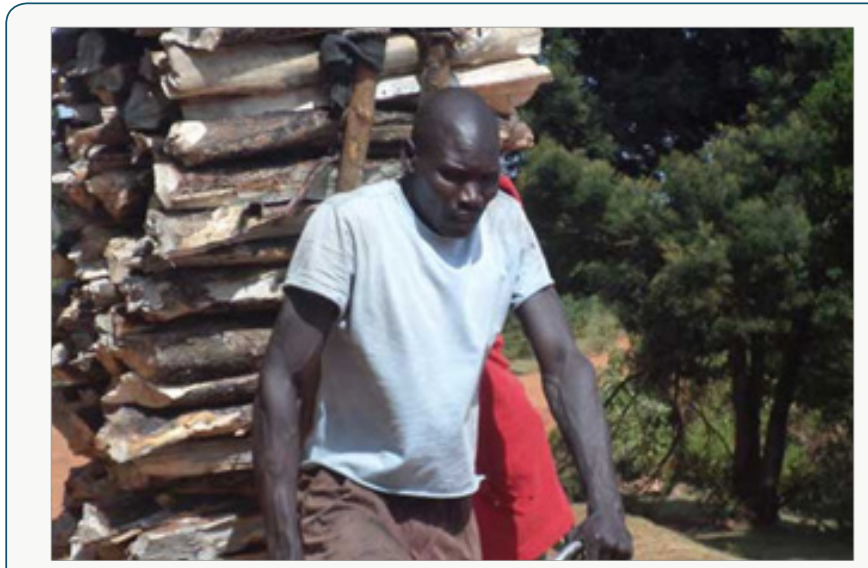

Plate 1: A man with fired wood collected in Kaptagat forest, Mau complex.

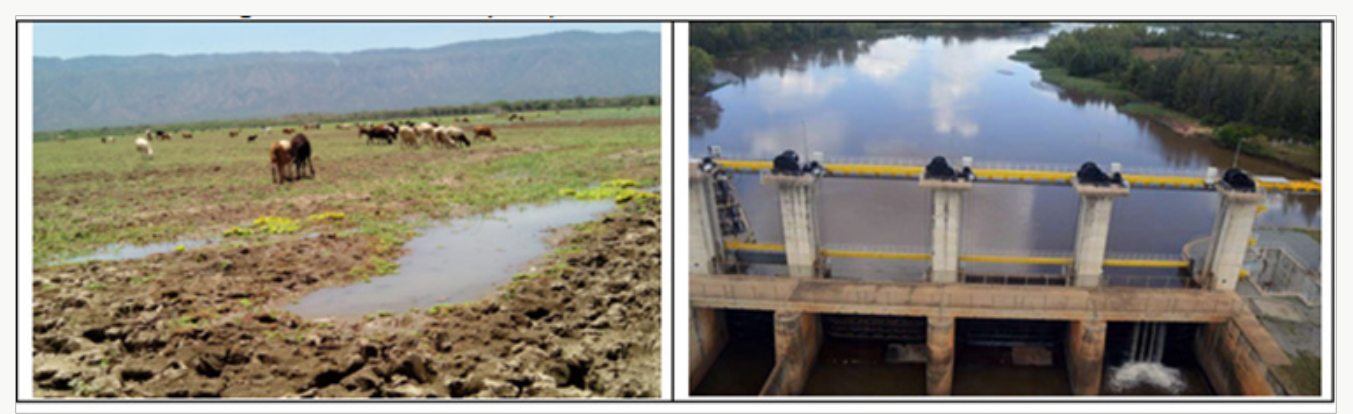

Plate 2: a). Lake Kamnyarok as it dries and water d windles b, Sondu-Miriu hydroelectric power plant in Nyakach, Kisumu County, on February 14, 2018 and currently operating at half capacity due to the declining water levels.

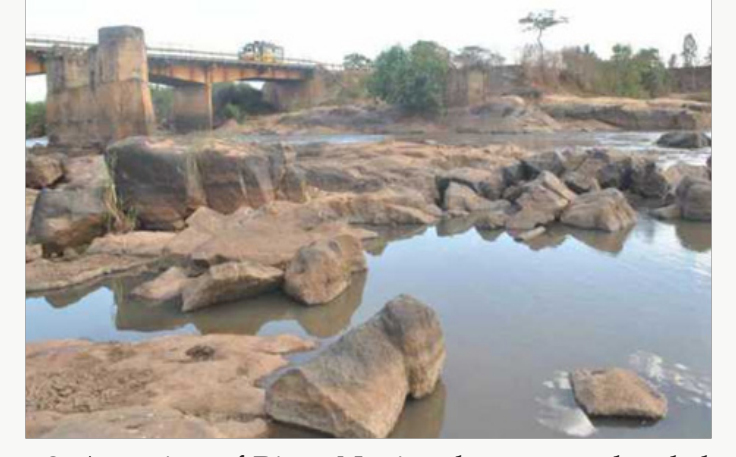

Plate 3: A section of River Nzoia where water levels have reduced due to prolonged dry season [Duncan Ocholla, Standard, February 2018].

The donors funding the restoration of the lake demanded that the residents to vacate the place while the residents demanded compensation before giving up though there are indications that the land is an officially declared National Reserve. Though earlier attempts to conserve the lake failed, the KWS director has been hoping that the residents of the Barwessa Division will follow the example of the residents of the Rimoi Game Reserve where land reverted to the government and conservation effected as the county council of Baringo aimed to save the reserve from extinction. For L. Baringo, the situation has been aggravated by poor land use resulting in siltation and output from fishing and forestry sectors in particular has declined substantially due to resource degradation [9]. L. Baringo is one of the important fresh water lakes in the Kenyan Rift Valley that is primarily arid in nature and as a significant world Ramsar site, it is important in terms of socio-economic diversity and biodiversity. Despite this, the lake is threatened with siltation resulting from human activities in its catchment. A study by Lwenya [10] on Human aspects of siltation, Causes, Impacts and Interventions to identify the factors contributing to siltation and to suggest strategies and opportunities to mitigate the problem indicated that the livelihoods of communities around L. Baringo depend on livestock rearing, charcoal burning and cultivation all precursors to degradation of the ecosystem.

Socio-economic factors, including poverty, land fragmentation; low standard of living and earning are cited as drivers contributing to the increased risk of watersheds [11] due to differences in land uses and land utilization types. Land ownership influences socioeconomic and political position and benefits of different groups 
of people. Land issues and conflicts that occur are related to poverty, inequality and land reformation processes. Contestations over land are most noticeable among the poor folks, who lack alternative means of supporting their livelihoods [12], leading to lack of resources conservation. Transition from forest to another agricultural use leads to significant impact on topsoil resistance and resilience [13]. For most wetlands, soil erosion by water is the most common process causing sedimentation downslope and on riverine valleys meaning there is a distinct linkage between erosion and watershed conservation [14], and these are accelerated by deforestation, overgrazing, and the cultivation of unsuitable or fragile land (plate 4) [15].

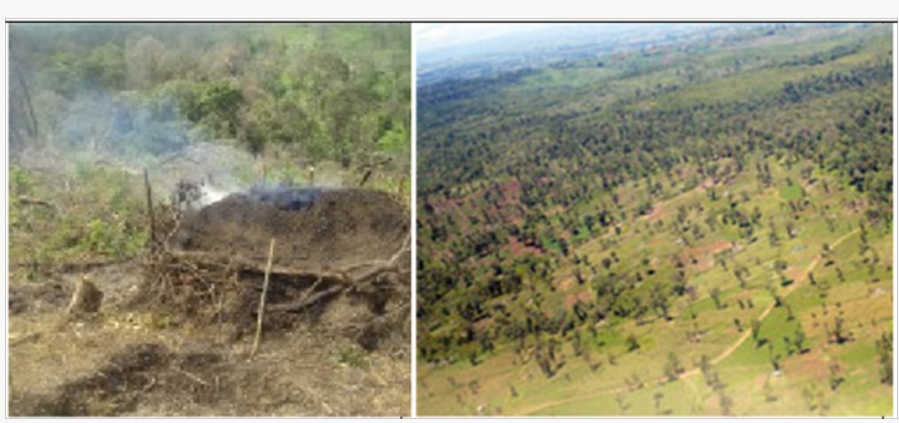

Plate 4: Mau Forest Complex, one of Kenya's most important water catchments, is severely threatened by unsustainable exploitation such as forest clearing for charcoal production.

L. Ol'Bolossat watershed has been affected by anthropic disturbances [16]. In the headwater catchments of the central Kenya, a prevalent cause of land degradation is unplanned deforestation to allow for human settlements and subsistence agriculture. In the highlands of Nyandarua, the ubiquitous landuse changes are believed to be the major cause of the dwindling volumes of L. Ol'Bolossat (Plates 5-7), which has recently been declared an endangered water body by the regional government of Kenya [17]. So far, few studies have been carried out on the spatial-temporal lands cover changes possibly affecting the size of L. Ol'Bolossat hence lack of reliable in-situ data. Accumulation of organic matter and silt from the surrounding farmlands have contributed to water pollution and fluctuation of water level from zero to $250 \mathrm{~cm}$ depending on rainfall, surface run off and seepage from the basin [18]. The lake suffers domestic and agricultural pollution due to unsustainable farming practices that lead to occurrence of waterborne diseases [19]. According to the forest Act 2005, Kenya Forestry Services (KFS) has the mandate of managing Kenyan Forests. The law allows for collaboration and participation of the local community living adjacent to the forest to conserve the forest in question and in return earn a living through extraction of non-wood products.

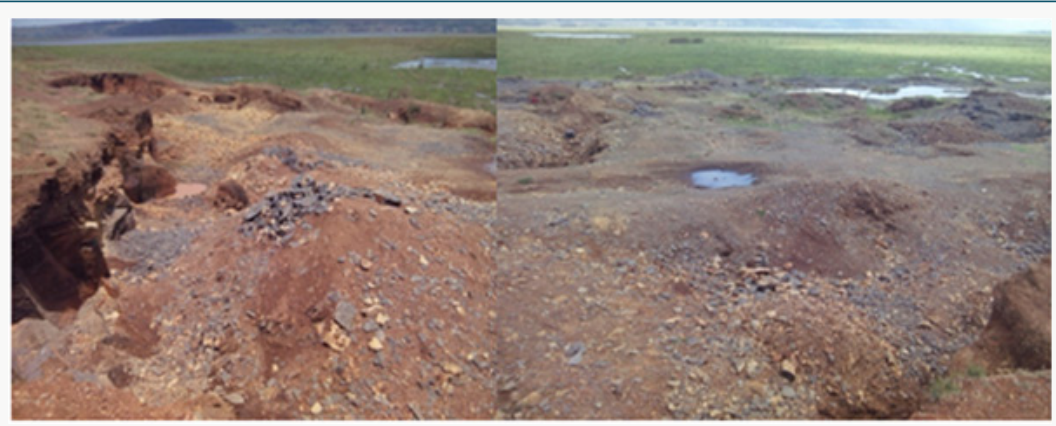

Plate 5: Quarrying near the lake Ol'Bolossat: Photograph taken $11^{\text {th }}$ February 2016.

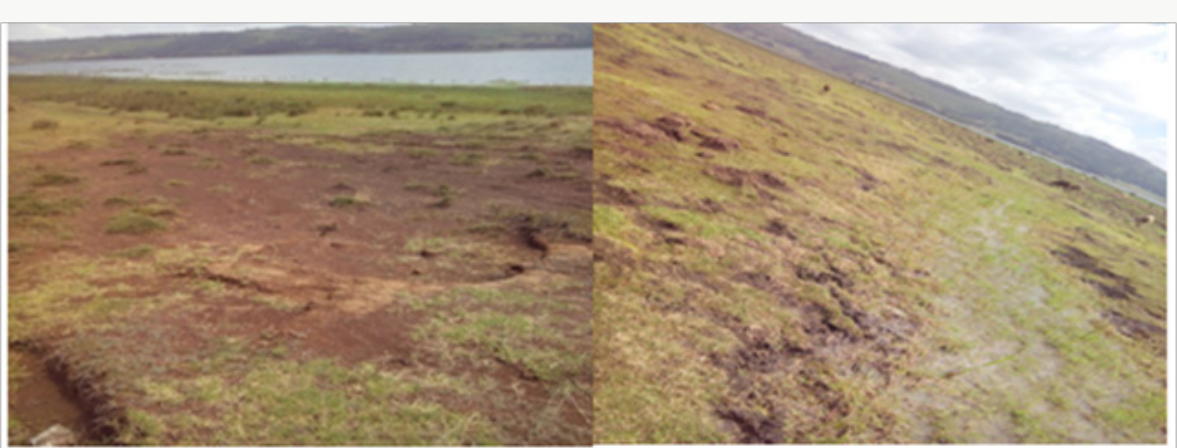

Plate 6: Effects of erosion into the lake Ol'Bolossat: $11^{\text {th }}$ February 2016. 


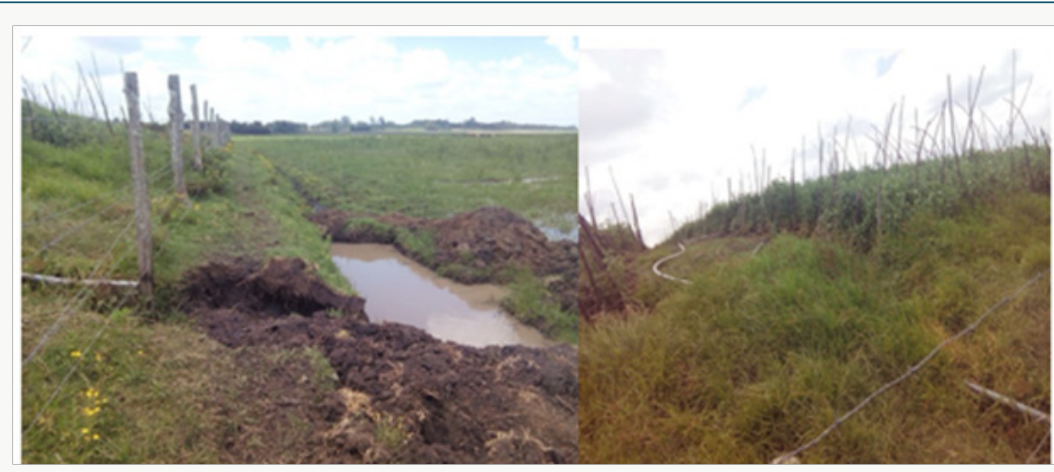

Plate 7: Water abstraction from the lake Ol'Bolossat for agriculture: 11 ${ }^{\text {th }}$ February 2016.

The use of agrochemicals in neighbouring farms has led to bioaccumulation in fish and pose health risk to human as well as fish death and causes extinction of some species [19]. In 1992 the Fisheries department established that turbidity of $L$. Ol'Bolossat was not suitable for fresh water fish though mud fish could do well in those conditions. Nielsen [20] indicated that habitat loss and degradation ruin the fisheries through water abstraction, removal of vegetation for development and agriculture. Communally owned resources experience challenges when being shared; such as unequal sharing of resources, dissimilar priorities, location of the resource, dissimilar cultures and unequal representation in the management [21]. These challenges are in turn manifested in poor conservation measures of L. Ol'Bolossat due to the tragedy of the commons. The free rider rationale where no individual community member bears responsibility. Poor land-use systems together with resource user conflicts, political marginalization, poverty, weak institutions and policies have been observed as factors contributing to land and water degradation. Negative impacts of siltation as identified above included destruction of fish breeding areas, flooding, poor water quality affecting human and animal use and increased resource user conflicts. Strategies that various institutions are undertaking such as replanting indigenous vegetation, are show little progress due to poor or lack of co-ordination, the nature of the landscape, lack of funding and political goodwill. Lwenya [10] identified opportunities for soil management systems such as use of indigenous trees and grasses to enhance livelihoods for local communities, while at the same time conserving the soils. Which in most cases are ignored by the local communities as was observed by Koech [22,23] in Bura irrigation Scheme and it surrounding areas.

A case in point is the now Controversial Mau water tower where the forests are diminishing very fast [19]. The Mau Forests Complex (MFC) forms the largest closed-canopy forest ecosystem in Kenya, the largest indigenous montane forest (417,000 hectares) in East Africa, and is the most important water catchment in the Kenyan Rift Valley and Western Kenya. Investigations show MFC has been affected by widespread unplanned settlements, irregular forest land allocation and illegal extraction of forest resources destroying approximately a quarter of the MFC over the last 15 years [24].

In addition, sections of the MFC have been impacted by forest plantations (10\% of Mau forest), subsistence and cash crop farming and unregulated logging concessions. Scientists predict that further destruction of the MFC will cause an environmental disaster in Kenya and significantly reduce river flows and lake levels. This has already been observed in the dwindling river Mara, Gucha and others feeding Victoria basin. The MFC forests provide critical environmental services to the country: freshwater provisioning, river flow regulation, flood mitigation, recharge of ground water reservoirs, erosion control, water purification, biodiversity conservation and micro-climate regulation. The ecosystem services support a range of economic sectors including agriculture and tourism and the market value of such goods and services generated annually in tea and tourism sectors alone, in excess of US\$ 229 million [24]. The restoration of the MFC is of major interest to the government of Kenya and is now a national priority. The politicization of the removal of encroachers from several forest blocks in the southern MFC demonstrated the importance of the ecosystem and the extent of the vested interests involved [23].

The role of trees in agricultural production and water catchment has become starkly apparent in Kenya following the now well-known encroachment and degradation of the Mau forests complex. The complex is one of Kenya's five water towers, the others being Mt. Kenya, Aberdare ranges, the Cherangani Hills and Mt. Elgon (http://www.agriculturesnetwork.org/magazines/ east-africa/62-trees-farming/mau-forest-degradation\&http:// www.agriculturesnetwork.org/magazines/east-africa/62-treesfarming/mauforest-degradation\#sthash.jcM9RLhc.dpuf). It is also argued that forest complex biodiversity and habitats provide vital ecological services to the country, in terms of water storage; river flow regulation; flood mitigation; recharge of groundwater; reduced soil erosion and siltation; water purification; conservation of biodiversity; and; micro-climate regulation. Through these ecological services, the forests complex supports key economic sectors in Rift Valley and western Kenya, including energy, tourism, agriculture, and industries. The negative impact of the degradation of the Mau forest has been felt most by farmers along the valleys through which rivers originating from the forest drain as well as the tea and tourism industries in the neighbourhood. Production of tea is only possible in the vicinity of tropical forests, a crop which is among the highest earner of foreign exchange in Kenya, requires a cool climate which can only exist in the proximity of established 
forests such as the Mau complex. The Mara and Ewaso-Ng'iro rivers which feed the Masaai Mara Game reserve and L. Natron (flamingos breeding site), respectively, originate from the Maha.

http://www.agriculturesnetwork.org/magazines/eastafrica/62-trees-farming/mau-forestdegradation). The threat posed by the encroachment and degradation of the Mau over the decade between 1995 - 2006 led to a sustained public outcry that in 2007 compelled the Government to set up an Interim Coordinating Secretariat (ICS) for the Restoration of the Mau Forest. To date the Secretariat has not only managed to halt the encroachment and about 70 per cent of forest destruction, but has also put in place sustainable measures to restore the forests complex in collaboration with Kenyan Forest Service and other development partnersn (http://www.agriculturesnetwork.org/magazines/eastafrica/62-trees-farming/mau-forest-degradation). This initiative was spearheaded by Kenya's Prime Minister, Rt. Hon. Raila Odinga in 2008 at the point where more than 100,000 out the total of 416,000 hectares had disappeared. One of the most dramatic manifestations of this destruction was that the then newly constructed multimillion shilling Sondu Miriu Hydro Electric Project could only achieve 50 per cent of its potential power production (http:// www.agriculturesnetwork.org/magazines/east-africa/62-treesfarming/mau-forest-degradation).

Restoration of degraded soil calls for the application of certain management and conservation measures and the undertaking of much needed precautions. Measures such as contour cultivation, tied ridging, terracing, strip cropping, dense vegetation and planting of cover crops, mulches, fast growing trees, selection of proper crop rotation, quick growing species and integrated cropping system, provision of alternative fuel sources, check structures, protected watersheds, proper land preparation and ploughing, application of fertilizer, amendments and organic manures and drainage systems are quite often mentioned as the techniques which help to protect and improve the land [25]. Soil and water conservation programs have gained recognition in the world as a means of water management. In the 1970 and 80's, much emphasis in Kenya was on soil erosion control by structures such as gabions to convey and direct runoff away from agricultural land. Soil and water conservation, however, is now embraced as a tool for the management of soil and water land resources in order to satisfy the needs of the land users through sustained agricultural production [26].

About $80 \%$ of Kenya's land mass is ASAL and supports 35\% human and 50\% livestock populations [26]. The masses are poor and depend on relief food supply for survival. To improve production systems, the ministry of Agriculture through National Soil and Water Conservation Program (NSWCP) in Soil and Water Conservation Branch $[27,28]$ initiated the soil and water management activities. These entailed water conservation, water harvesting and water management. These activities increases the amount of water stored in the profile by use of bench terraces, tied ridges, fallow, contour fallows, mulching, rotations, mixed cropping and conservation tillage techniques as well as soil fertility improvement practices. Water harvesting, the collection and concentration of runoff was for the production of crops, trees, fodder and pasture establishment [28] and also for domestic and livestock purposes. The term harvesting is used instead of water conservation or water management. Water management is the efficient or economic management of available water in agriculture, and use of subsurface and surface resources in agricultural production. In broad terms, it encompasses conservation, harvesting, control, regulation and use of water in agriculture.

In Kenya, the severity of soil erosion was realized as early as the 1920s. In an attempt to arrest the situation, compulsory terracing schemes were introduced in the 1940s, but they were unpopular because the benefits were unclear to the local people. Some techniques developed during this period were and are effective but the fact that they were based on enforced communal work meant that soil conservation was bitterly resented by the local people $[29,30]$. Many terraces fell into disrepair around the time of independence (1961) and indeed the programs catalyzed resistance and armed struggle against the colonial regime [31,32]. By 1961, the relative proportions that were terraced in KangundoMatungulu-Mbiuni in Agro-ecological zone 3 (high potential land) and Masii in zone 4 (semi-arid upland) were essentially the same as those of 1948. After independence however, terracing was renewed voluntarily and farmers began to construct them within a few years of opening new land, even in the newly settled areas of Makueni (drier, warmer and lower zone 4 and 5 settled after 1945), where average slopes were less steep. Un-terraced arable land had been virtually eliminated in all three areas by 1978 where significant progress was made between 1961 and 1978, when arable area was itself growing rapidly due to increased population. Terrace construction continued in the 1980s, and was promoted by the Machakos Integrated Development Program and by 1980, erosion on arable land was considered to be under control. The problem was, however, only beginning to be solved on grazing land.

Little conservation happened immediately after independence in 1963, until a new soil and water conservation campaign began in the 1970s. This campaign started up just at the time when people were becoming increasingly concerned about the future of their farmlands. People were now anxious to listen to advice, and were ready to participate in conservation activities, where slopes were steep and erosion rate high due to unstable soil structure. Erosion was worsening due to the expanding cropped area while draught spells regularly affected yields, especially maize. Enforced conservation did not work in colonial times but in the 1970s people were ready to respond to new campaign as they envisaged accrued benefits to their efforts. This implied that awareness and communal participation in decision making bore fruits that were lacking in pre-colonial times, 
Machakos has the reputation for being the district with the best soil and water conservation in Kenya [29]. The national conservation project was initiated in1974 under Swedish International Development Agency (SIDA) sponsorship where field work in Machakos district commenced in1979 and was later expanded to the whole country in 1989. At community level, farmer-based soil management practices and mechanical measures have been practiced ever since and have been largely successful, particularly in semi-arid Eastern Kenya, and included Strip cropping, contour farming, ridging, mulching \& rotation and physical techniques such as terracing, cutoff drains among others. The main soil and water conservation measures practiced here are grouped into agronomic, soil management and mechanical. Agronomic include increasing soil surface cover, intercropping, contour farming, cover cropping and agro-forestry, increasing soil surface roughness, and increasing both surface depression storage and infiltration. Soil management measures include application of fertilizers, manures, sub-soiling to break the hardpan, buffer strip, crop rotation and drainage while mechanical measures include contouring, ridging and terraces [25]. Field experiments in semi-arid regions of Kenya have shown that soil water conservation techniques can result in increased maize grain yields. The degree of benefit in a particular season is dependent on rainfall amount and distribution [33]. In Meru Central district conservation measures have been undertaken but at a lower scale compared to Machakos District. Agricultural productivity is very high in this humid mountainous area where most farms are for commercial production of wheat, barley, flowers and Asian vegetables. Small scale farmers grow tea as a cash crop. The NSWCP lasted from 1974 to 2000 [34]. In the last 10 years of the program, a catchment approach was emphasized where efforts and resources were concentrated in a catchment for 1 year. Problems and opportunities were identified within the land years in a participatory manner, and subsequent development activities planned. A baseline study found that both human activities and changing environmental conditions contributed to environmental degradation in Meru District. Concerted project interventions were undertaken to protect and sustain the mountain environment in $\mathrm{Mt}$ Kenya region. Physical or mechanical soil conservation structures used in this area are permanent features made of earth, stones or masonry. They are designed to protect the soil in the hilly area from uncontrolled runoff or erosion, and retain water where needed. They supplement agronomic or vegetative measures but do not substitute for them. The appropriate type of physical structure to use depends on i) climate and the need to retain or discharge runoff water; ii) farm size; iii) soil characteristic such as texture, depth and drainage patterns; v) availability of an outlet or waterway to discharge excess water; v) availability of labor and, vi) adequacy of existing agronomic or vegetative measures.

\section{Types of Conservation Measures in Kenya}

Soil and land management practices such as tillage and cropping practices, directly affect the overall soil erosion problem and solutions on a farm. When crop rotations or changing tillage practices cannot effectively control erosion on a field, a combination of measures might be considered necessary. For example, contour ploughing, strip cropping, or terracing may be considered. The most practiced measures in Kenya and elsewhere involves:- (i) Agronomic such as plant/soil cover, conservation farming methods, contour farming (ii) Vegetative: such as planting barriers (vegetative strips), live fences, windbreaks (iii) Structural: such as Fanya Juu, terraces, banks, bunds, cut off drains, barriers and lastly (iv) Overall management: such as area closures, selective clearing. For more examples and description of the conservation measures refer to sections below depending on Soils and Agro-climatic zonation:

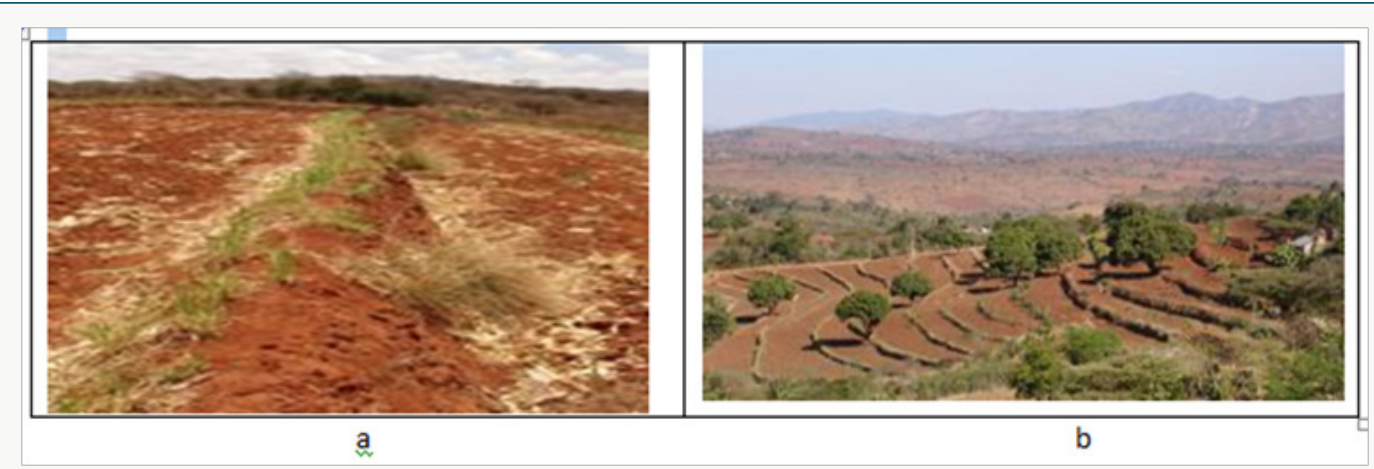

Plate 8: a). Fanya juu bund in maize field after harvest. Note Napier grass strip on upper part of bund, and maize trash in ditch below. b). Fanya juu terraces in a semi-arid area which have developed over time into benches. Note the well-established grass strips along the bunds @Hanspeter Liniger, WOCAT.

\section{Terraces}

Leveled bench terraces and earth banding on existing slopes are common earth structure in Kenya. Sometimes, and especially in the highlands, steps are constructed across hillsides and strips of crop residues are covered with soils dug from above. The resulting incorporation of organic matter increases soil fertility and enhances infiltration [35] through macro porosity as well as increased water retention in soils [36,37]. The fanya juu earth bunding system is now modern tradition in Kenya [38]. The fanya-juu terrace (Plate 8) is designed to trap run-off and suspend sediment. A trench is dug and soil thrown upslope to form an embankment which is very effective in trapping runoff and there is evidence crop 
performance is increased [33]. The challenge however, is the high labor requirement in their construction and maintenance [39]. Though fanya-juu terracing is laborious, it is well understood by the people of Eastern Kenya, and has shown to be effective. Mwangi [40] observed highest maize yields in terraced compared to all other conservation measures in sloping land. Machakos district has achieved an average 1,000 km of new fanya-juu terraces constructed each year, as well as several hundred kilometers of cut-off drains since the mid-1980s. The conservation campaign has been so effective that it is estimated that $70 \%$ of all cultivated land has now been terraced as the farmers, many of whom are women, have recognized the benefits of terracing. Conservation of moisture and also soil has led to better and more reliable crop yields. The remaining are mainly in the lower, drier areas where more attention and campaign should be focused now. A fanya chini is like a fanya $j u u$, except that the soil is put on the lower side of the contour trench, not on the upslope side as in a fanya juu. Fanya chini are used to conserve soil and divert water. The resulting embankment can be used to grow fodder. Fanya chini are easier to make than fanya juu, but they do not lead the formation of a bench terrace over time. They can be used on slopes up to $35 \%$.

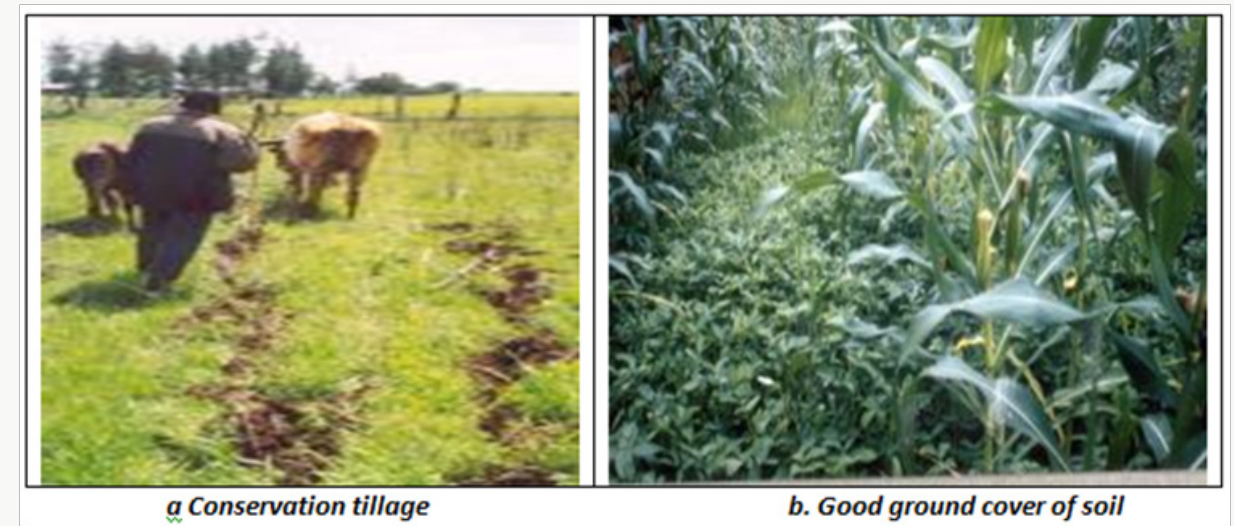

Plate 9: a). (OWill Critchley, Amsterdam, the Netherlands and b). CCeris Jones, London, UK (Reproduced from WOCAT, www.wocat.net).

\section{Conservation Agriculture in Kenya}

There are three major principles on conservation agriculture practised in Kenya: minimal soil disturbance, permanent soil cover and crop rotations (Plate 9a \& 9b). Soils under conservation agriculture tend to considerably improve their soil organic matter (SOM) content after applying the technology for several years. SOM can be considered as the most important soil fertility and quality factor influencing other soil properties such as macro porosity, infiltration, water holding capacity or soil structure. In conservation agriculture, only minimal or no soil tillage is applied and involves crop seeding without mechanical seedbed preparation and minimal or no soil disturbance since the harvest of the previous crop [25]. A number of farms are practising minimal tillage through precision farming such as Acacia farm in Athi River and Mr Sessions' farm in Naro Moro. The process involves use of Global Positioning (GPS) to minimize on soil compaction to an efficiency of $99 \%$ where deviation from ruts for truck and tractor wheels is less than 1 degree. The farm traffic uses same axle size and moves on same position season by season during farm operations to minimize compacting the whole land area. The crop residues after harvest are all returned to the farm where they decompose and add to the organic carbon pool. This has the added advantage of holding more moisture after rains especially in these ASALs and improving soil friability and resilience. Yields have been observed to increase tremendously in these low rainfall areas and a promise to food security in the region.

\section{Cover crops for soil fertility and erosion control}

Cover crops is any annual, biennial or perennial plant grown as a mono- or poly-culture to improve any number of conditions associated with sustainable agriculture [41]. Cover crops are fundamental sustainable tools used to manage soil quality $[42,43]$, water, weeds, pests, diseases and diversity in an ecosystem. Keeping the soil covered is a fundamental principle of conservation agriculture. Crop residues are left on the soil surface to protect soil surface after harvesting or during kill-down when the cover crops are slashed and left in the field at flowering [36,37]. Additional cover crops may be needed if the gap is too long between harvesting one crop and establishing the next. Cover crops improve the stability of the conservation agriculture system, not only on the improvement of soil properties but also for their capacity to promote an increased biodiversity in the agro-ecosystem [44,45]. Cover crops are beneficial in stabilization of soil moisture and temperature, protect the soil during fallow periods, mobilize and recycle nutrients, improve the soil structure and break compacted layers and hard pans $[42,43]$, permit a rotation in a monoculture, control weeds and pests and produce additional soil organic that improve soil structure. Cowpea (Vigna unguiculata) for example is an important grain legume in the tropics and subtropics and is an ideal cover crop due to its drought tolerance, grow even in very poor soils with very little water and fix di-nitrogen from the atmosphere. It yields eatable grains and can be used as an animal fodder rich in protein. 
Agro-ecosystems are ecological systems managed by humans across a range of intensities to produce food, feed and fiber. To a large extent, humans shape ecological structures and functions of natural processes that occur in agro-ecosystems. As agro-ecosystems often interact with natural ecosystems in agricultural landscapes, cover crops that improve sustainability of the agro-ecosystem attributes may also indirectly improve qualities of neighboring natural ecosystems. Farmers in Kenya and in fact the world over choose to grow specific cover crop types and to manage them in a specific way based on their own unique needs and goals. The latter are influenced by biological, environmental, social, cultural and economic factors of the food system which farmers operate [46]. In Kenya and parts of south eastern Africa, where smallholders grow velvet bean (Mucuna pruriens), hairy vetch (Vicia villosa) and sunhemp (Crotalaria juncea) as cover crops. Velvet bean have long and short cycle varieties, are excellent ground cover and dies off during dry season. The short cycle variety produce edible white seeds and in some communities, leaves are used for tea. Hairy vetch is a high altitude forage crop, whereas sunhemp is a forage plant of the sub-humid and semi-arid regions and is more a shrub than a cover crop. Cover crops use water during their cycle in the farm and thus affect water relationship of the next crop $[47,48]$.

Effects are positive when cover crops are managed to improve infiltration and reduce evaporation [37], or remove water from waterlogged soil to allow timely establishment of the next crop. The effect could be negative when cover crops limit water for the next crop or aggravate a wet soil condition [47]. Cover crops have an influence on physical soil properties such as water relationships, aggregation, infiltration capacity, bulk density, soil temperature and hydraulic conductivity. Cover crops influence soil water content through reduced surface evaporation due to mulch effect and increased infiltration and retention of precipitation $[37,49]$. Judicious use of cover crops residues, either incorporated in the soil or placed on soil surface can help in maintaining adequate infiltration rates [50], preventing soil surface crusting [51], improving soil aggregation $[52,53]$, modifying the transport and retention of water [37], heat [54-56] and aeration in soil [57]. Mannering and Mayer [58] found that final infiltration rates into a typic Argindoll were increased from 2.3 to $5.3 \mathrm{cmhr}^{-1}$ when $2.2 \mathrm{Mgha}^{-1}$ of wheat straw was mulched on the surface. Greenland [59] reported that runoff from tropical Nigerian soil (Paleustaff) was five times greater where crop residues were ploughed under than for no-tillage system with crop residues remaining on the soil surface. Scapel [60], modeling crop residue mulching effects on water use and production of maize under semi-arid and humid tropical conditions, observed that even small amounts of surface residue are effective at reducing water loss and increasing yield.

Some cover crops have been shown to suppress weeds, reduce nematode loads, improve soil fertility, reduce water leaching and control erosion. Kamidi [61], in a study at Matunda farm in Kenya, observed velvet bean produced more biomass than other cover crop species. Velvet bean relay crop was also shown to improve the performance of subsequent crop by over $40 \%$ and farmers preferred it more as it increased maize yield when used together with half recommended rate of DAP inorganic fertilizer $\left(30 \mathrm{kgP}_{2} \mathrm{O}_{5}\right.$ ha $\left.^{-1}+30 \mathrm{kgNha}^{-1}\right)$. Land productivity in Central Kenya is constrained by low productivity due to continuous cultivation without replenishment [62] hence the need to incorporate cover crops [37]. Cover crops or green manure are grown and incorporated (by tillage) into the soil before reaching full maturity, and are intended to improve soil moisture, soil fertility and quality. Studies carried out in the central highlands and in western areas of Kenya have shown sunhemp (Crotalaria ochroleuca); velvet bean (Mucuna pruriens) and purple vetch (Vicia benghalensis) enhance moisture retention in the soil [63]. Sunhemp cover crop was found to accumulate $7.2 \mathrm{Mgha}^{-1} \mathrm{DM}$ and $111 \mathrm{kgNha}^{-1}$, though continuous cultivation resulted in buildup of soil-borne diseases [61]. Some cover crops exhibit allelopathy and can suppress growth of other crops as observed in field experiments in central Kenya. Velvet bean roots incorporated into the soil reduced tomato yields among cover crop residue combinations, a fact attributed to the allellopathetic nature of velvet bean roots $[36,37]$. Hairy vetch has been shown to suppress initial growth and development of water melon. Cropping systems should be designed in such a way that the soil is almost permanently covered with plant canopy to conserve water by curtailing excess evaporation and soil loss by wind and water erosion. In arable crops, careful timing of sowing and planting can help to avoid uncovered soil being washed away during the rainy season. After the main crop is harvested, a green manure cover crop may be sown to cover the ground and on the slopes, crops should be grown in contour lines across the slopes (along the contour lines) rather than vertically. This can contribute enormously to reduce the speed of surface water/runoff thus avoid denudation [43] as well as sedimentation of water bodies' downslope and other offsite damages.

\section{Green manure}

Green manure are plants grown to accumulate nutrients for the main crop where they penetrate the soils with their roots, deliver nutrients and support infiltration of water into the soil. The contribution of organic matter to the soil by green manure crop is comparable to the addition of 23 to $33 \mathrm{Mgha}^{-1}$ of farm yard manure [64]. Leguminous plants fix nitrogen $(\mathrm{N})$ from the air into the soil and this $\mathrm{N}$ enriches the soil and feeds plants in the area. The portion of green manure- $\mathrm{N}$ available to a crop planted later is usually about 40 to $60 \%$ of total amount of $\mathrm{N}$ contained in the legume. For example, a purple vetch crop that accumulated $225 \mathrm{kgNha}^{-1}$ prior to ploughing into the soil contributes approximately $113 \mathrm{kgNha}^{-1}$ to the succeeding grain or vegetable crop [64]. Lower amounts are available for the second or third crop following a legume, but increased yields are apparent for 2-3 growing seasons. When they have built up maximum biomass, they should be worked into the surface soil. And because they are usually cut before flowering, 
growing a green manure is thus different from growing a legume crop in rotation. Once worked into the soil, the fresh plant material rapidly releases nutrient and become fully decomposed within a short period of time $[37,48]$. Aged or coarse material such as straw and twigs decompose at a slower rate than fine material and therefore contribute to the buildup of SOM content [64]. An alternative to sowing a green manure crop in the field is to collect fresh plant material from elsewhere and work it into the soil (biomass transfer) as done by Rutunga [65] in Western Kenya. He observed that trees and /or shrubs growing alongside crops in agro-forestry systems could provide large quantities of green material which can be used as green manure. Tithonia diversifolia for example, accumulates high concentration of nutrients in its leafy biomass, which then mineralizes very rapidly when incorporated in the soil. Green leaf biomass of Tithonia diversifolia harvested in Western Kenya is high in nutrients, in order of 3.5-4.0\% N; 0.35 $0.38 \% \mathrm{P} ; 3.5-4.1 \% \mathrm{~K} ; 0.59 \% \mathrm{Ca}$ and $0.27 \% \mathrm{Mg}$ on dry matter basis [65].

\section{Agro-Forestry in Kenya}

Agroforestry describes land use systems where trees are grown in association with agricultural crops pastures or livestock-and there are usually both ecological and economic interactions between components of the system. Farmers have practised agroforestry for years. Agro-forestry as a land use system in which trees and shrubs are grown in association with crops in the same land unit, has the potential to arrest land degradation and rural poverty of dry lands through service and production functions. Various agroforestry technologies have had enormous application in Kenya and have lifted many out of poverty as well as mitigating declining agricultural productivity and natural resources. Notable examples are: a) fertilizer trees such as Calliandra spp, Leucena Leucocephala, Terminalia brownii among others that when combined with inorganic fertilizers double or triple crop yields in degraded lands; b) fodder trees that are used in smallholder zero-grazing systems in ways that supplement or substitute commercial feeds; c) improved varieties of temperate and tropical fruits that are used to supplement household incomes and nutrition; d) medicinal trees that are utilized on farm and conserved in-situ; and e) fast growing timber and fuel trees that can be grown in various niches within the farm and in commercial woodlots and plantations [66]. While thousands of smallholder farmers are using these technologies in the eastern province of Kenya, millions of others that need them are yet to be reached. To achieve this goal, the key challenges that must be addressed include supply of quality germplasm, responsive extension services especially at county level, and legislation on policies that provide adequate incentives for investments in planting trees and natural resource management, and access to markets through improved infrastructures. In many areas, most of the fruits produced end up rotting in the field due to these setbacks. Recently Makueni County have seen tremendous improvement in the same after setting a processing fruit factory that is benefiting many farmers in the area (https://www.makueni.go.ke/makueni- fruit-processing-plant-opened). These are institutional innovations for better managing the complex nexus between poverty, food security, and natural resource management in the dry lands such as in Kenya [66].

Traditional agroforestry systems take the form of trees scattered on crop fields, woodlots, homestead tree planting and multi-storey home gardens [67]. This system requires pruning trees of branches and tops to reduce shading. The service functions of trees are numerous and include improving soil fertility, conserving soil moisture and improving micro-climate resulting in increased crop yields. Many of these trees are multipurpose, providing a range of benefits with proven impacts that includes poverty reduction through agroforestry products for home consumption and sale; food security through restoration of farm soil fertility for food crops and production of fruits, nuts and edible oils; through negotiation support, ensuring, a fairer deal for women farmers and other less-advantaged rural residents whose rights to land are insecure; reducing deforestation and pressure on woodlands by providing fuelwood grown on farms; Increasing diversity of on-farm tree crops and tree cover to buffer farmers against the effects of global climate change; Improving nutrition to lessen the impacts of hunger and chronic illness associated with HIV/AIDS and augmenting accessibility to medicinal trees, the main source of medication for more than $80 \%$ of Africa's population. Experiments conducted in Ethiopia have shown that wheat and maize yields increased by over $50 \%$ under Faidherbia albida canopy (within $1.4 \mathrm{~m}$ radius) compared to those further away from the base of the tree $[68,69]$. Similar success story have been observed in Kenya through agro forestry. (http://www.worldagroforestry.org/news/ reaping-rewards-agroforestry-kenya). Planting trees and shrubs on earth structures such as soil and stone bunds, terraces and raisers combines soil conservation with production of various products such as fodder, fruits and fuel wood. This has made the land to be utilized more productively as trees use the area along the structures where crops cannot be grown. The challenge to guard against is some of the species introduced for soil conservation becoming invasive weeds such as Prosopis juliflora which was a very good fodder initially but has now become ecological disaster in the ASALs of northern Kenya [70].

\section{Hedges}

Hedges are used to conserve soils in Kenya on a contour. A contour hedge is a horizontal strip of multipurpose trees or shrubs that is used to control soil erosion on sloping lands. These hedges provide high quality fodder (e.g. Lucerne hedges), firewood, stakes for climbing beans and mulch material to conserve soil moisture in the field. Contour hedges control erosion by providing a physical barrier as well as through increased water infiltration as a result of leaf litter layer creating good soil structure. Over the long-term, these hedges have resulted in the formation of terraces on the upper side of each hedge [66], an added advantage in soil and water conservation measures. 


\section{Improved fallows}

Improved fallows have been used in some areas, where land is left to rest (fallow) from cultivation and is enriched with leguminous trees to speed up soil fertility replenishment. Common leguminous trees and shrubs such as Sesbania sesban, Tephrosia vogelii, Gliricidia sepium, Crotalaria grahamiana and Cajanas cajan were used to rapidly replenish soil fertility in one or at most two growing seasons [66]. A maximum of 3 years have been cited as necessary to replenish fertility in extremely degraded soils through improved or planted fallows [71]. The trees and shrubs are interplanted with crops such as maize during the rainy season and are left to grow during the dry season tapping soil water with their deep taproots. Right before the next rainy season, farmers harvest the fallows, remove fuel wood and incorporate biomass (leaves, soft stems and leaf litter) into soil prior to planting maize in Eastern Kenya. In western Kenya, maize yield following improved fallows averaged 4.1 $\mathrm{Mgha}^{-1}$ which is much higher than those from non-fertilized plots continuously planted with maize at $1.7 \mathrm{Mgha}^{-1}[72,73]$. Fallows improve soil structure, ease tillage and facilitate conservation tillage [73]. Fallows increase soil's water infiltration capacity and are capable of deep root development $>7 \mathrm{~m}$. Fallows also reduce soil erosion, by maintaining a leafy canopy during dry seasons and more vigorous crop growth during rainy seasons. Better soil conservation results have achieved when fallows were combined with contour hedges planted to fodder species [70]. It can therefore be argued that productivity on degraded lands can be restored and food security effectively achieved with conservation practices country wide. In a survey in western Kenya, over 16,000 farmers were using improved fallow in 2000 [70]. The only challenge now is the increased population which has made it almost practically impossible to leave land fallow for more than a season. This in itself does not allow land to recover and regenerate adequately to realize the accrued benefits of fallowing. But for those in ASALs and with large tracts of land, the benefits cannot be overemphasized.

\section{Vegetation strips}

Vegetation strips are usually narrow grass strips grown across slopes. The grass acts as a barrier to runoff thus encouraging deposition of sediments and eventually leading to terrace development. The commonly planted grasses in Kenyan degraded lands are Imperata cylindrical, Vetiveria zizanioides Austin 2017 and Pennisetum purputeum. Species such as Pennisetum purputeum are also used as fodder to draft animals and other livestock hence dual purpose. Live fences surrounding cultivated fields acts as modification of vegetative strips [35]. Fodder grasses are planted on top of the terrace bank to hold the earth together and these benefits the farmer from a source of valuable cattle feed, and land which might otherwise have been unproductive is put to good use.

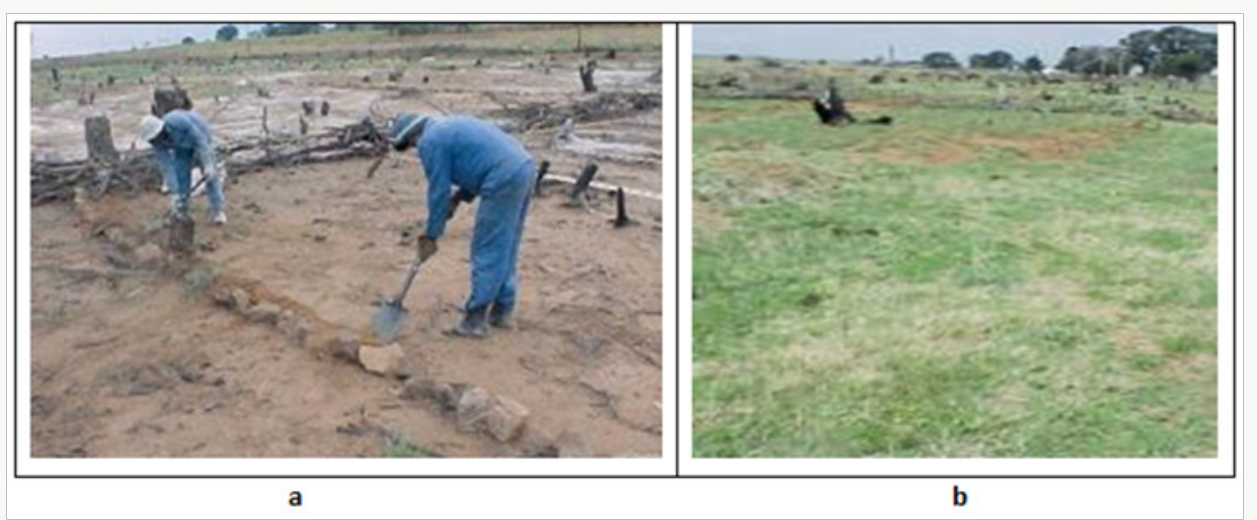

Plate 10: a). Rehabilitation of degraded rangeland in its initial stage: stone lines are established after the area has been cleared of invasive tree species and b). Over sowing with grass seeds, manuring with cattle dung and applications of lime speeds up regeneration of the grass cover.

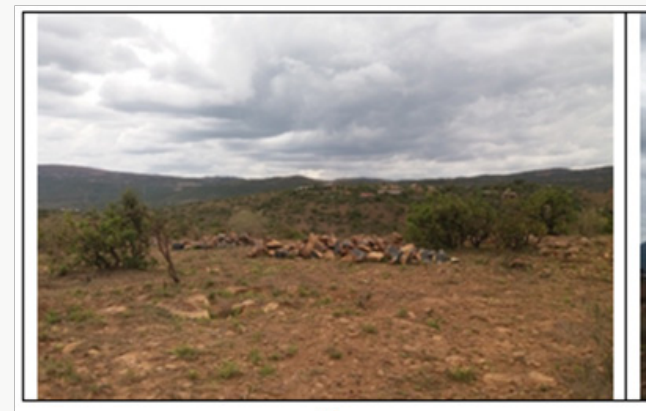

a

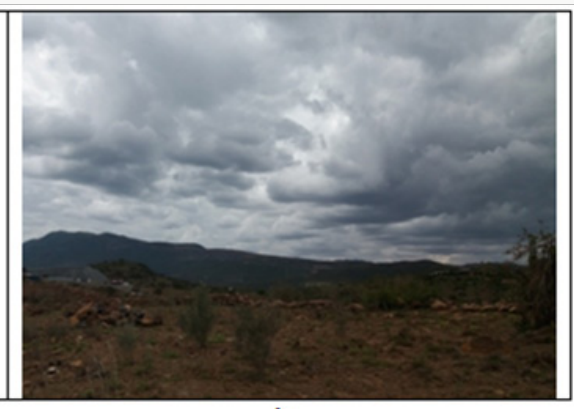

b

Plate 11: a). Natural stones piled to the left for high pasture improvement and building a home in Kisamis, Kisamis, Kenya. b). In the background a stone fence plus a mound of gravel from the quarrying in Kisamis, Kisamis, Kenya. 


\section{Conservation/Regeneration Measures}

\section{Land use change, area closure and rational grazing}

Management measures are often applied to grazing land in situations where uncontrolled use has led to degradation and where other measures simply do not work without a fundamental change in land management. Enclosures are used for protection from grazing and thus allow regeneration of vegetation cover. Such measures are essential for the rehabilitation of badly degraded areas where technical measures and other interventions are often not adequate on their own but can act in a supplementary manner (Plates 10-12). Other measures include intensification of grazing land use where fodder crops are planted and used for cut-and-carry feeding of livestock. Management measures are advantageous in that they do not involve very high capital investments or labour. It should be noted that taking land out of use can lead to increased pressure on neighbouring land, which may also be in poor condition and vulnerable to further degradation. The challenge in management measures is that they are not clear-cut, they require great flexibility and responsiveness at initial stages and in subsequent years that follow. There are also implications for land tenure that can complicate decision-makings that may sour relationships between neighbours [74] as they try to conserve their land holdings.

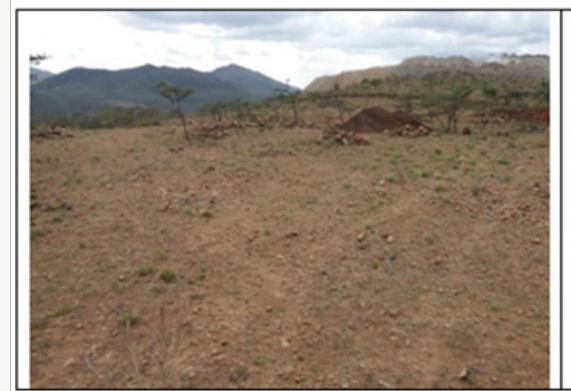

a

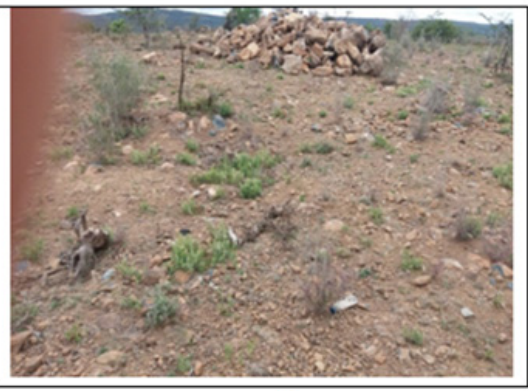

Plate 12: a). Red soil brought from Kiambu for tree. b). Natural stones piled for pasture improvement planting in Kisamis, Kenya.

\section{Contour farming}

Contour farming involves ploughing, planting and weeding along the contour, across the slope rather than up and down. Contour lines are lines that run across a hillslope such that the line stays at the same height or altitude and does not run uphill or downhill. As contour lines travel across a hillside, they will be close together on the steeper parts of the hill and further apart on the gentle parts of the slope. Research show that contour farming alone can reduce soil erosion by as much as $50 \%$ on moderate slopes. However, for slopes steeper than $10 \%$, other measures have been used in combination with contour farming to enhance its effectiveness. Caution is mostly observed to avoid incorrectly establishing contour lines as they risk to actually increasing erosion. Contour ridges are commonly used ASALs to harvest water, and in the humid- higher rainfall areas for growing potatoes. Trash lines made by laying crop residues or "trash" (Plate 13) in lines along the contour have been shown to slow down runoff and trap eroded soil, eventually forming terraces. Research however, have shown that contour lines can be destroyed by termites eating the trash thus compromising the conservation agenda envisaged. To overcome this setback, grass barrier strips, for example fodder grass such as Napier is planted, or the contour left with natural grass. These are effective soil conservation measures on soils that absorb water quickly, and on slopes as steep as $30 \%$.

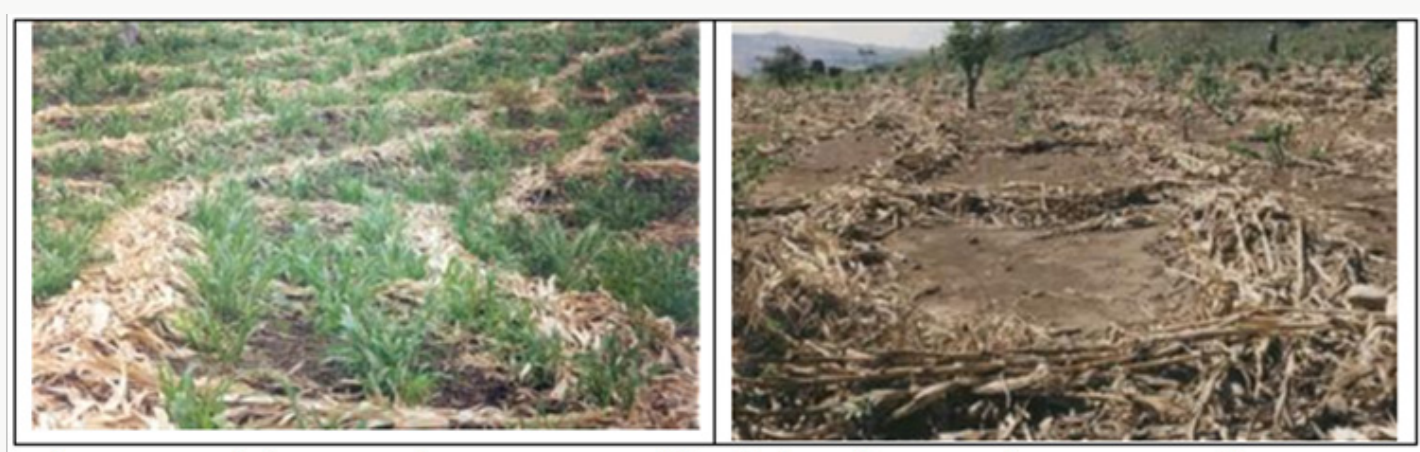

Plate 13: Trash lines @Berhanu Fentaw, Addis Ababa, Ethiopia and @H. Krüger from WOCAT, respectively (www.wocat.net).

\section{Trash lines}

Trash lines range from simple bunds of cereal and legume Stover to more sophisticated pegged brush lines according to Gichuki
[75]. Apart from impeding runoff and enhancing infiltration, trash lines also increase soil organic matter content when incorporated into soil during ploughing, enhance soil macro porosity, water 
holding capacity, soil hydraulic conductivity as well as improve soil fertility upon decomposition and mineralization [37]. Trash lines are extensively used in the Tharaka area of Meru [76] in Northern Kenya. Trash lines though with no much support from government are used as a traditional soil conservation measure since colonial times in Kenya. Their effectiveness depends on the size of the bunds and their spacing. Large trash lines have been shown to reduce erosion, increase both infiltration and available water to crops leading to increased crop yields $[11,77]$.

\section{Cutoff drains, retention and infiltration ditches}

Cutoff drains are usually dug across a slope to intercept surface runoff and carry it safely to an outlet such as a canal or stream with minimal risk to aggravating erosion. They are used to protect cultivated land, compounds and roads from uncontrolled runoff, and to divert water from gulley heads [77]. Retention ditches are dug along a contour to catch and retain incoming runoff and hold it until it seeps into the ground. They are an alternative to cutoff drains when there is no nearby waterway to discharge the runoff into. They are used to harvest water in semi-arid areas. Infiltration ditches are one way of harvesting water from roads or other sources of runoff and consist of a ditch, 0.7-1.5m deep, dug along a contour, upslope from a crop field. When it rains, runoff water is diverted from the roadside into the ditch, which is blocked at the end to hold the water. Water trapped in the ditch seeps into the soil and maybe used for rain harvesting agriculture where moisture is stored in the ground. This is has been used in the semi-arid area in Baringo district in the Kenyan Rift Valley area for increased food production [9].

\section{Broadbeds and furrows}

In a broadbed-and-furrow system, runoff water is usually diverted into field furrows $30 \mathrm{~cm}$ wide and $30 \mathrm{~cm}$ deep. The field furrows are blocked at the lower end to hold the water and when one is full, the water backs up into the head furrow and flows into the next field furrow. Between the field furrows are broad beds about $170 \mathrm{~cm}$ wide, where crops are successfully grown.

\section{SWOT Analysis on Soil Conservation in Kenya}

Soil and water conservation processes in Kenya can be summarized into strengths, weaknesses, opportunities and threats (SWOT) where crop residues are considered herein

\section{Strengths}

Merits of soil conservation includes: Advantages of mulch are similar to those of crop residues in that they increase water infiltration [37,78], decrease run off [78], and have greater soil water availability than such materials as saw dust and wood shavings. In relation to increasing infiltration, studies in Kenya reported that in a $12 \%$ slope of well-structured freshly cultivated soils, where $4 \mathrm{Mgha}^{-1}$ of grass mulch equivalent to $79 \%$ cover reduced runoff from simulated rainfall to $5 \%$. This is an indication that at $80 \%$ cover, equivalent to $4 \mathrm{Mg} \mathrm{ha}^{-1}$ maize straw, would be appropriate for increasing rainwater infiltration hence its conservation in soil.

Both residues and mulches provide additional benefits, notably less water loss by direct surface evaporation, less weed incidence, softer and more workable soils and increased earthworm activity $[36,34,79]$. After residue incorporation, there are additional nutrients $[37,80]$ released into the soil and subsequently increased yields. In western Kenya, mulching with Tithonia spp has given substantial yield increase of maize (Zea mais), Kale (Brassica oleracea), tomatoes (Lycopersicon esculentum) and French beans (Phaseolus coccineus). The net profit of mulching kale ranged from USD 91 to $1,665 \mathrm{ha}^{-1}$ [81]. In the semi-arid areas west and north-west of Mount Kenya, maize yields increased by a factor of 4.4 when $3 \mathrm{Mgha}^{-1}$ of mulch was applied [82]. A substantial number of farmers have increased crop yields using improved fallow and a local administrator in Siaya district, Kenya, summarized the results of the first year thus: "For the first time there have been no hunger periods in Luero village. Only ears of maize have been reported stolen this year (July, 1998). One farmer from Vihiga district, western Kenya reported his annual cash income to have increased tenfold with the sale of kale planted following improved fallows [66].

When soils are badly degraded that they must be taken out of production, soil porosity can be restored through the action of biological processes. This has been achieved by following for one or several years under natural vegetation enriched with fast-growing leguminous trees, or planted fallows. The accumulation of large amounts of biomass on the soil surface from the fallow vegetation associated with high biological activity and strongly developed root systems promote the biological recuperation of soil porosity as witnessed in Bamburi/Haller park nature trials at Mombasa, Kenya. Here land has been reclaimed from a quarry and a tourist park established that generates much revenue through local and foreign exchange earnings. Biological incorporation of residues into the surface soil resulted in higher organic matter content in upper few millimeters of soil, which progressively extended into deeper layers overtime. The permanent cover of surface residues encourages soil faunal activity, which in combination with higher soil organic matter contents leads to improved soil porosity FAO. The work is still progressing as new quarried land is being restored. Well adapted leguminous cover crop are currently being adapted in many marginal lands of Kenya as they often speed up the recuperation of soil porosity compared to a natural vegetation fallow because larger amounts of biomass are rapidly produced by the cover crop such as velvet bean [37]. Whereas natural vegetation fallow may require 3-5 years, a cover crop may restore initial soil porosity in 1 year.

Conservation measures in agro-forestry systems have tremendously improved the supply of fuel and forest products such mangoes in Siakogo, Embu and Makueni Counties in Eastern Kenya(https://www.makueni.go.ke/makueni-fruit-processingplant-opened) thus boosting farmers' incomes. It appears that an integrated approach with appropriate macro-economic policy 
framework for input and output markets as well as land tenure, provision of services such as education, health, agricultural extension and adequate infrastructure such as transport, water and electricity have played a major role in reversing land degradation in Kenya (http ://siteresources.worldbank.org/ KENYAEXTN / Resources /ERS.pdf).

\section{Weaknesses or demerits associated with conservation}

Cost of labor for collecting, transporting and applying mulch is prohibitive to the peasant farmers (http://siteresources. worldbank.org/KENYAEXTN/Resources/ERS.pdf). This is not the case with cover crops residues, which are produced on-site unless for biomass transfer Runtunga 1999. Often there are no suitable mulching materials in the vicinity of the farms, or labor is insufficient when required. Transporting large quantities of mulch for large scale cropping is seldom economical as there is a cost of slashing the cover crop though not the case for smallholders. Similarly, lopping trees and distributing branches and leaves over the cropping area requires considerable labor. On steep slopes, the application of residue cover crops is not easy and these materials are easily washed downhill. Mulching cannot be applied after emergence of closely spaced crops as it smoothers them thus interfering with their growth and performance. Mulching materials and crop residues are often grazed by cattle belonging to the farmer, the community or landowner (in case of tenant farmer), fed to livestock, or sold as fodder hence a conflict of interest amongst competing uses. Sometimes thee materials are in high demand for thatch or fuel.

In ASALs, mulches are rapidly consumed by termites, and in hot humid climates, they decompose rapidly [37]. Use of mulch progressively decreases soil fertility (mining) with time, where mulching materials are produced, unless manures or fertilizers are applied. Soil erosion may also degrade the source areas where the cover crop is provided by the vegetation is removed for use as mulch in another location. Use of covers is more common in subhumid and humid zones because of the greater productivity and thus availability of vegetative materials. Nevertheless, they are particularly suited to semiarid areas when materials are available and in the absence of severe termite problems. Mulches are often applied to limited areas of high-value horticultural crops and homegardens in easily accessible fields with gentle slope. Peasant farmers have difficulties affording them. Constraint of soil recuperation by natural vegetation fallows in mechanized production systems is that of eliminating trees and excavating roots before returning them to cropping. If manual system is applied, the problem is less serious. Herbaceous and shrubby cover crops can be eliminated much more easily by slashing or mowing and the subsequent crop may be sown directly into the residues of the cover crop.

A problem exists of inadequate supply of appropriate germplasm material and a lack of transport [70] to the intended sites on time and this normally inhibits or delays farm operations. Crop production in semiarid areas involves a lot of risks, including flooding and draught. This makes it difficult for farmers to realize the full benefits of soil conservation. Irregular rainfall reduces the effectiveness of vegetation erosion control practices. Global concern about deforestation caused by fuelwood shortages prompted the introduction of Prosopis juliflora to many tropical areas in the 1970s and 1980s. P. juliflora is a hardy nitrogen-fixing tree that is now recognised as one of the world's most invasive alien species. The introduction and subsequent inva $\neg$ sion of $P$. juliflora in the Garissa-Tana River (Plate 14) and Baringo areas of Kenya has attracted national media attention and contra $\neg$ dictory responses from responsible agencies. A publication by Mwangi [83] assessed the livelihood effects, costs of control and local perceptions on $P$. juliflora of rural residents in Baringo area. They noted that unlike some other parts of the world where it had been introduced, few of the potential benefits of $P$. juliflora had been captured and very few people realised the net benefits in places where the invasion was most ad 7 vanced. Strong local support for eradication and replacement appears to be well justified. Mwangi [83] advanced that sustainable utilisation of Prosopis would require considerable investment and institutional innovation. In some areas, Prosopis juliflora used as strips have turned into weeds [70], affecting crop performance, while in others, species such as Eichornia crassipes (Water Hyacinth) choke water bodies such as Nairobi dam and $L$. Victoria waters.

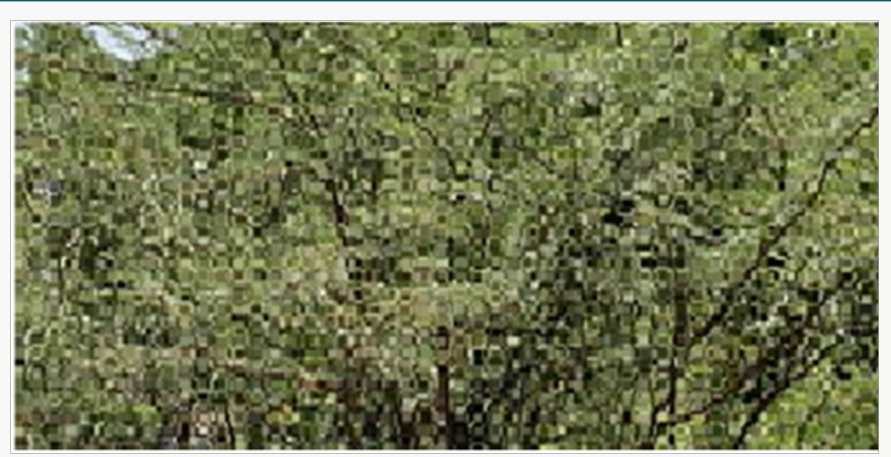

Plate 14: Prosopis juliflora invasive weed along Garissa Bura Road, Kenya.

Water and nutrient competition is also common in agroforestry leading to low yields. Calliandra spp. has been reported in the lower dry areas of Embu county, Kenya to compete effectively with maize crop for moisture (Personal communication 2009). Some of these 
challenges involve centralized planning by experts, planning on basis of geographical area rather than natural village units of land, and too much emphasis on soil erosion rather than conservation of moisture for plant productivity. These factors need to be addressed by the Government and other stake holders to build on the current soil conservation measures.

\section{Opportunities}

Runoff control and runoff harvesting produce significant crop yield increases in average years. Water conservation strategies may therefore allow for earlier planting or be accompanied by increased planting densities, both of which may result in yield increase [84]. More land maybe brought under agriculture or pastures through water harvesting and erosion control on steep lands. The outcomes will be higher incomes and better nutrition to the people who are therefore healthy and productive [9]. The environment will also be conserved hence less pollution. Current and on-going research on Prosopis juliflora for biofuel and animal feeds may lead to better utilization of the noxious weed as well as fertilizer formulation from both Prosopis juliflora and Eichornia crassipes [85].

\section{Challenges}

Conservation measures suggests that population growth and agricultural intensification are compatible with environmental recovery [30]. However, it would be a misinterpretation to imply a constantly positive effect of population growth and land quality and health. Even for places like Machakos County where positive effect is evident, signs indicate it may be necessary to slow down population growth in order not to exceed the optimum population size, given the prevailing natural resources, infrastructure and services (http://povertyenvironment.net). The proximity to Nairobi, and therefore markets for agricultural products, has greatly enhanced the adoption of conservation in Machakos and subsequent economic growth. Indeed, other regions in Kenya may not be as fortunate in terms of nearby markets. Developing the necessary infrastructure to open up regions for trade is therefore an important motivation strategy as farmers need incentives to invest in costly conservation measures. It is evident that yields are now declining in areas that have been under permanent cultivation for the longest time since conservation measures were introduced in the early 1940s. In such areas, efforts are required to ensure the sustainability of agricultural production. When degraded soils are severely compacted, deep tillage with subsoiling immediately prior to sowing the cover crop encourages establishment and development of cover crops. If the degraded soil is severely deficient in phosphorus, the application of $\mathrm{P}$ fertilizer becomes necessary to encourage establishment of the cover crop. Obare [86] summarises the Underlying causes of deforestation and forest degradation and possible solutions in Kenya as follows:

\section{Poor Policy Formulation and Enforcement}

Land polices in totality often tend to be agrarian favouring large-scale commercial farmers. They are inconsistent as their application varies from region to region or sector or to sector depending on the land tenure systems leading to mis-use, confusion, non-use and indiscriminate destruction of resources with eventual degradation some of which might be irreversible as the soils loses their resilience.

\section{Political Expediency}

Due to political rivalry, forests are usually given to supporters of particular politicians as a bribe or repayment for political patronage.

\section{Macro-economics}

Cash crop production for export: Intensification of cash crop farming is on the increase on cleared forest land with major examples being flowers, horticulture, tea and coffee. These cash crops are grown for export to industrialized nations and compete in the world market for the much needed foreign exchange earnings. The indigenous communities such as the Ogieks (forest dwellers) have claimed in the past that pyrethrum and pesticides applied on the farms kills bees and have rendered bee keeping unviable hence not a suitable alternative for harvesting of honey in the forest.

Liberalisation: The liberalisation process has put a lot of emphasis on the privatisation of public land and forests resulting in the non-recognition of customary resource tenure. The Ogieks have been denied their ancestral rights to the forest land they occupy.

Structural adjustment programmes: As a result of the restructuring process in government involving such measures as retrenchment in public sector and reduction of budget allocations to various ministries and departments, ministries such as that of environment and forestry department are not spared. Most of the personnel such as forest guards are declared redundant making it difficult to manage the forests efficiently thus encouraging illegal use of the resource. Currently there is demotivation due to poor police officers' pay [87] with some threatening mass resignation thus affecting forest destruction through logging activities that is decimating our tree cover.

Population pressure: Most of the Kenyan people are concentrated in the agricultural land, about $20 \%$ of the country's area. This means a lot of strain being exerted on forest land which is seen as free land for potential use. A lot of excision has taken place in forests such as Ngong, Mau and Hombe in Mt Kenya just to name a few. In Mau forest, those neighbouring the forest would like to reap benefits from it and some pressures their politicians for such land regardless of the loss in the ecosystems functions.

\section{Actors}

Those responsible for the underlying causes at different levels include:

\section{Local level}

Farmers growing cash crops who continue to increase the area under cultivation to get more income. The county governments 
continue allocating land to these farmers without considering conservation versus degradation issues.

\section{National level}

The policy makers do not have the good will to incorporate the lifestyle of the indigenous communities such as the Ogieks, Masaai and Ndorobos in their national plans. The governments, both at national and county level should train their staff to recognise the role of indigenous knowledge in forest conservation to curb further degradation. Political leaders keen on distributing land to gain mileage without considering long term effects of destroying the catchment areas should be censured or even blacklisted from holding public office to streamline this anomaly. Some indigenous tribes such as the Ogieks are not represented in parliament by one of their own and attempts have been made in the past to assimilate them into other communities leading to further marginalisation.

\section{Global level}

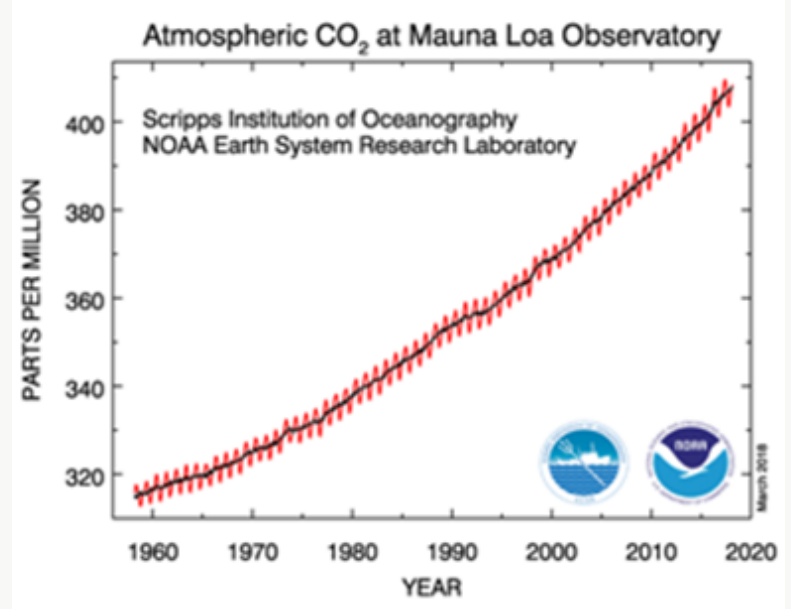

Source 1: https//upload.wikimedia.org/Wikipedia/ commons/1/15Mauna_Loa_Dioxide.

The industries and consumers in developed world promote export of cash crops in bulk as raw material with no value addition. Structural adjustment programmes advanced by World Bank that are economically oriented with little or no regard to sustainable environmental conservation have led to encouragement of intensive exploitation of forest land leaving communities vulnerable to the vagaries of nature and more so climate change, global warming as more $\mathrm{CO}_{2}$ is released into the atmosphere due to poor carbon sequestration. Globally averaged concentrations of $\mathrm{CO}_{2}$ reached 403.3 parts per million (ppm) in 2016, up from 400 ppm in 2015 (https://www .theguardian.com /environment /2016/ sep /28 / the-world-passes-400ppm-arbon-dioxide-threshold-permanently) because of a combination of human activities and a strong El Niño event," according to The Greenhouse Gas Bulletin [88], the UN weather agency's annual flagship report [89]. These two actors operate behind the scene (Source 1). They influence those at local level as they come up with the measures on how to run the global economy. The decision made by them will determine the kind of national plans in place and therefore influence affected local communities.

\section{Oversight Discussion on Soil and Water Conserva- tion}

Crops grown under soil incorporated or mulched with cover crops have been observed to have higher yields and better water use efficiency than those grown traditionally without any conservation measures. [37] Working at Kabete, Kenya found yields and WUE of tomato (Cal J) was superior than control plots where Mucuna, Sunhemp and vetch were mulched or incorporated in a Nitisol. Kenya is favoured by having high-altitude areas of good agricultural potential where most of the population lives. Nevertheless, Kenya suffers occasional food shortages. One of the reasons for this is that over three quarters of the country is, in fact, ASALs and these areas are home to an increasing number of people as the country's population rises at about $4 \%$ per year; one of the fastest growth rates in Africa. Agricultural production is also threatened in many parts of the country by soil erosion. Soil conservation techniques for the highland areas are well developed and the conservation activities of self-help groups in places like Machakos County in eastern Kenya are particularly effective unlike in most other parts of the country. In the more arid areas, such as Turkana district in the far north-west, water harvesting is needed for dryland cropping to be possible. Several projects testing systems of water harvesting as a viable water conservation technique for Kenya are currently in available.

The lower rainfall in semi-arid areas compared with that in humid climates does not mean a corresponding low level of soil erosion by water in these places. Indeed rainfall erosion has been observed to be higher in ASALs than in many other climatic zones. This is partly because the semi-arid areas have a high proportion of convective thunderstorm rain of high intensity and high erosive power. There is also poor protective vegetative cover at the beginning of the rainy season and some of the soils common in in these areas are particularly vulnerable, either because they have poor resistance to erosion thus high erodibility, or because of their chemical and physical properties and low organic matter content. For example, alfisols suffer a particularly high loss of productivity per unit loss of soil [90]. Gully erosion as witnessed in Kalama, Machakos County can be severe in these semi-arid climates and the benefit/cost of gully control needs to be considered when conserving these lands. Successful but expensive gully conservation like the Australian one for example might not be suitable for third world countries like ours with budgetary constraints [91].

There are always strong links between measures for soil conservation and measures for water conservation, and this applies equally in semi-arid areas. Many measures are directed primarily to one or the other, but most contain an element of both. Reduction of surface run-off by structures or by changes in land management help in reducing erosion. Similarly, reducing erosion usually involve 
preventing splash erosion, or formation of crusts, or breakdown of soil structure, all of which increase infiltration, and so help the water conservation. In arid and semi-arid areas, rain falls only during a few months in a year, but is unreliable even during those few months. It typically comes in a few, heavy storms, and much of the water runs off the surface, causing flooding and erosion. Water conservation relies on trapping as much of this water as possible and storing it on the surface (in tanks or reservoirs) or allowing it to sink into the soil in order to raise the water-table and increase the soil-moisture level. Unfortunately there is no clear cut policy or legislation towards water harvesting in Kenya even in teaching institutions like Universities and research stations that should take the lead unless it is for postgraduate research. Little or no funds are allocated for such activities by the government and even for this postgraduate research; the money is sourced through calls from outside donors [92-99]. A lot of water that could be harvested on hillsides, roads, rocky areas or even rooftops goes to waste only for the inhabitants, county and national government leaders to lament there afterwards when the rains are gone and the dry season sets in. Even where storage pans are dug, it is at a very small scale and cannot sustain the locals when the draught is prolonged like was the case recently. At present rains are pounding the whole country with roads being washed away as in Mai Mahiu, floods bringing buildings down in Nairobi and environs [87] but not a single water harvesting venture has been put in place either by county or national government. More water can seep in if it is spread over a large area of soil rather than being concentrated into fastrunning streams. So water-conservation efforts should focus on stopping the water from becoming concentrated in the first place by ensuring a protective cover of vegetation on the soil surface, slowing down the flow of running water by directing it into pits and dams [100-105], and spreading the water out over a large area (for example, via contour ditches) and above all, enhance the infiltration of water into the soil by improving the physical soil quality with conservation tillage techniques that aid in percolation [106].

\section{Integrated Programmes}

The current approach by soil conservationists unlike in the 1980 s is moving away from using mechanical works and structures in soil conservation programmes that were paid for by a government or donors such as increasing awareness of the ineffectiveness of terracing programmes alone. Conservationists are now moving towards the view that the only effective programmes which have the full support of the local people benefit [107]. The subsistence farmer cannot afford to respond to philosophical or emotional appeals to care for the soil, and this means that conservation measures must have visible short-term benefits to the farmer such as increased yields per unit of land, or perhaps better production per unit of labour, or perhaps improved reliability of yield. The idea of local communities working together in groups on tasks which require a big labour force is well-established in many countries, particularly for planting, harvesting or building structures. The practice can now be successfully extended to conservation works with advantages such that the village group can tackle jobs too big for an individual or family; generates a sense of communal care for the land and these work groups are a good forum for extension workers to encourage improved farming methods [108].

\section{Conclusion and Way Forward}

\section{Possible actions to counteract the underlying causes of land and forest degradation in Kenya}

Decision Makers should be re-oriented on the need to involve local stakeholders in policy formulation. The formulation of an integrated and comprehensive land policy geared towards attaining sustainable development is key and should consider natural resources holistically not sectoral and also harmonise what is in existence. This means restricting decision making process and policy intervention to ensure collaborative forest management and security of tenure to the rightful individuals, community and the governments. Management of the forest should be done by a board of trustees drawn from various forest stakeholders and should be people of integrity, incorruptible and devoid of politics. A bill should be tabled in parliament at National level, and in the county assembly in the devolved units that empowers ministers at these levels and ensure that decision making process is consultative right from grassroots level.

The village council of elders should be revived for the purpose. Disciplinary measures through harsh penalties for those destroying forests either through illegal logging or charcoal burning should be the norm without political interference. Elaborate measures should be put in place to allow the public accessibility to timely and relevant information as a means of empowering them and building their confidence in participation. This is more so even where the National or county Government plan massive infrastructure developments through these fragile ecosystems such as the recent Standard gauge railway line from the port of Mombasa to the capital city Nairobi or the proposed LAPPSSET project from Lamu port in the ocean to South Sudan. Advocate for sustainable forest management such as the on-going Forest Action Network in Mau that is creating awareness among the Ogiek community living there on policy and legal issues. This helps in sensitising them on their rights to the forest resources. The project has been documenting information on the Ogiek's traditional forest management practices, and organising workshops for different stakeholders of the Mau forest to enable them work out a plan of action for achieving sustainable forest management.

Advocacy at Global level to sensitise the consumers and industries on accepting goods such as forest products, cash crops that are sustainably produced and the World bank prevailed upon to come up with environmental responsive polices and action plans. Promoting conservation of forests through sustainable harvesting of products and reforestation. A program to re-establish forests in marginal lands should be advanced in areas such Mara to save the ecosystem from collapse. Promote activities that reduce 
the pressure off forests like sericulture, butterfly and chameleon farming, improved bee-keeping, folder banks especially in arid areas like Kajiado and northern Kenya and bio-intensive agriculture and farm forestry. Precision farming is also playing a major role in and around Athi-River in Acacia farm and in Naro-moru Sessions' farm. Facilitate markets and value addition process to existing product such honey, medicinal plants and other plant and animal species with economic benefits to the communities. Build capacity on forest users to enhance technology base on relevant fields such as biodiversity enrichment and management regimes. Monitoring physical and environmental changes using advanced technology such as remote sensing and GIS with a view of counteracting the observed changes in order to enhance potential of the forest.

\section{References}

1. AQUASTAT-FAO (2005) Review of agricultural water use per country. Online publication FAO Rome, Italy.

2. AQUASTAT-FAO (2006) Water a shared responsibility. The United Nations World Water Development Report.

3. International Monetary Fund (2011a) Ethiopia, Gross domestic product per capita.

4. International Monetary Fund (2011b) Kenya, Gross domestic product per capita.

5. World Reference Base for Soil Resources (WRB) (2014) A framework for International Classification, Correlation and Communication. World Soil Resources Reports 106.

6. Haughn S (2016) The World's Waters: Hard Facts Point towards the Soft Path. Circle of Blue, the online independent news organization covering global fresh water crisis. The World Water 2008-2009. Biennial Report on Fresh Water Resources.

7. Gleick P (2009) The World's Waters, (ED.), Pacific Institute's, USA.

8. Kipsang E (2015) Human activity threatens important water tower.

9. Kinyali SM, Karuku GN, Tirop SK (1996) Impact of siltation problems on fish production in Lake Baringo, Baringo District, Kenya. EAAFRO Journal pp. 170-178.

10. Lwenya C, Yongo E (2010) Human aspects of siltation of Lake Baringo: Causes, Impacts and Interventions. Aquatic Ecosystem Health and Management 13(4): 437-441.

11. Wakindiki IC, Ben Hur M (2002) Indigenous soil and water conservation techniques: effects on runoff, erosion, and crop yields under semi-arid conditions. Australian journal of soil research 40(3): 367-379.

12. UNDP (2006) Human Development Report 2006 - Beyond scarcity: Power, poverty and the global water crisis. UNDP, USA.

13. Kocyigit R and Demirci S (2012) Long-term changes of aggregateassociated and labile soil organic carbon and nitrogen after conversion from forest to grassland and cropland in northern Turkey, Land Degrad Dev 23(5): 475-482.

14. Stocking M, Niamh M (2000) Land Degradation-Guidelines for Field Assessment, Overseas Development Group, University of East Anglia, and Norwich, UK.

15. Lal R (1988) Soil degradation and the future of agriculture in subSaharan Africa. J Soil Water Conserv 43(6): 444-451.

16. Karuku GN, Mugo EK (2016) Land use effects on watershed conservation: A case study of Lake Ol'Bolossat, Nyandarua County.
Research Project Paper presented at the Department of LARMAT. University of Nairobi, Kenya.

17. National Environment Management Authority (NEMA) (2007) Lake Ol Bolossat Management Plan 2008-2013. Kenya Wetlands Forum. Nairobi, Kenya.

18. Wamiti W, Malaki P, Mwangi A (2007) Survey of globally-threatened birds at Lake Ol' Bolossat Grasslands, central Kenya. Research Reports of the Directorate of Research \& Collections, National Museums of Kenya: Ornithology, 78.

19. Government of Kenya (2009b) National State of Wetland Ecosystem Report. Government Printer, Nairobi, Kenya.

20. Nielsen JR, Degnbo P, Viswanathan KK, Ahmed M, Hara M, et al. (2004) Fisheries Co management an institution innovation? Lessons from South East Asia and Southern Africa. Marine Policy 28(2): 151-160.

21. Okech RN (2010) Wildlife community conflicts in conservation areas in Kenya. African journal on conflict resolution 10: 65-80.

22. Koech OK, Kinuthia RN, Karuku GN, Mureithi SM, Wanjogu R (2015b) Water use efficiency of six rangeland grasses under varied soil moisture content levels in the arid Tana River County, Kenya. African Journal of Environmental Science and Technology 9(7): 632-640.

23. Koech OK, Kinuthia RN, Karuku GN, Mureithi SM, Wanjogu R (2016a) Irrigation levels affects biomass yields and morphometric characteristics of range grasses in arid rangelands of Kenya. 5: 1640.

24. Bird Life International (2013) Deforestation in the Mau Forest, Kenya, is impacting wildlife and people. Presented as part of the Bird Life State of the world's birds.

25. FAO-Food and Agriculture Organization of the United Nations (2007) Agriculture and Consumer Protection Department, Conservation Agriculture.

26. Mutunga K (2001) Water conservation, Harvesting and Management (WCHM) Kenya Experience. In DE Stotte, RH Mohar and GC Steinhardt (Eds 2001) Sustaining the Global Farm pp. 1139-1143.

27. Soil and water Conservation Branch (SWCB) (1997a) Soil and water Conservation Manual Ministry of Agriculture, Nairobi, Kenya.

28. Soil and water Conservation Branch (SWCB) (1997b) Water conservation, Harvesting and Management [WCHM]. Training-Kenyan Experience update, 1995-1997. Report by Mutunga, Ministry of Agriculture, Nairobi, Kenya.

29. Critchley W (1991) Looking after our Land, Soil and Water Conservation in Dry land Africa. In: Arid Lands Network and the International Institute for Environment and Development. UK, pp. 38.

30. Tiffen M, Mortimore M, Gichuki F (1994) More people, Less erosion: Environmental recovery in Kenya (Eds): John Wiley and Sons, Chichester.

31. Beinart W (1984) Soil erosion, Conservation and ideas about Development: A Southern African Exploration, 1900-1960. Journal of Southern African Studies pp. 52-83.

32. Anderson D, Grove R (1987) Conservation in Africa: people, policies and practice. Cambridge University Press, Cambridge, UK 25(2): 273.

33. William S, Hess TM (1999) Modeling the benefits of soil water conservation using the PARCH model-a case study from a semi-arid region of Kenya. Journal of Arid environments 41(3): 335-344.

34. Mwaura M, Mutunga K (2003) The Kenya National Soil and Water Conservation Program: A Report on Experience in Meru Central District, Mount Kenya. Mountain Research and Development 23 (1): 90-91. 
35. Thomas DB (1988) Conservation of cropland on steep slopes in Eastern Africa. pp. 140-149.

36. Karuku GN, CKK, Gachene, Karanja N, Cornelis W, et al. (2012) Soil hydraulic properties of a Nitisol in Kabete, Kenya. International Journal of Tropical and Subtropical Agroeco systems 15(3): 595-609.

37. Karuku GN, CKK, Gachene, Karanja N, Cornelis W, et al. (2014) Effect of different cover crop residue management practices on soil moisture content under a tomato crop (Lycopersicon esculentum).Tropical and Subtropical Agroecosystems 17(3): 509 -523.

38. Critchley WRS, Reij C, Willcocks TJ (1994) Indigenous soil and water conservation: A review of the state of knowledge and prospects for building on traditions pp. 293-314.

39. Kiome RM, Stocking MA (1993) Soil and water conservation in semi-arid Kenya. NRI Bulletin 61. Natural Resource Institute (NRI), Chatham, Kent, UK.

40. Mwangi JN, Mboya TO, Kihumba J (2001) Improved maize production in Central Kenya with adoption of soil and water conservation measures. $7^{\text {th }}$ Easter and Southern African maize conference. pp. 299300.

41. Lu YC, Watkins KB, Teasdale JR, Abdul Baki AA (2000) Cover crops in sustainable food production. Food Reviews International 16(2): 121157.

42. Mannering JV, Griffith DR, Johnson KD (2007) Winter Cover Crops Their Value and Management. Department of Agronomy, Perdue University. Purdue University Cooperative Extension Service West Lafayette, USA.

43. Birte J, Abaidoo R, Chikoye D, Stahr K (2008) Soil Conservation in Nigeria: Past and Present On-Station and On-Farm Initiatives. Soil and Water Conservation Society pp. 28.

44. Yadav RL, Dwivedi BS, Pandey PS (2000) Rice-wheat cropping system Assessment of sustainability under green manuring and chemical fertilizer inputs. Field Crops Resources 65(1): 15-30.

45. Prasad PVV, Satyanarayana V, Murthy VRK, Boote KJ (2002) Maximizing yields in rice groundnut cropping sequence through integrated nutrient management. Field Crops Resources 75(1): 9-21.

46. Snapp SS, Swinton SM, Labarta R, Mutch D, Black JR, et al. (2005) Evaluating cover crops for benefits, costs and performance within cropping system niches. Agronomy Journal 97(1): 322-332.

47. Unger PW, Vigil MF (1998) Cover crops effects on Soil Water Relationships. J Soil Water Conservation 53: 200-207.

48. Gachene CKK, Mwangi H (2006) Green manure cover crops for soil erosion control and conservation agriculture in Central and Eastern highlands of Kenya. In: Enhancing Agricultural Productivity in East Africa. Development and Up scaling of green manure legume technologies in Kenya. Published by Kenya Agricultural Research Institute (KARI).

49. Smith MS, Frye WW, Varco JJ (1987) Legume winter crops. Advances in Soil Sci 7: 95-139.

50. Adekalu KO, Olorunfemi I, Osunbitan JA (2007) Grass mulching effect on infiltration, surface runoff and soil loss of three agricultural soils in Nigeria. Bioresource Technology 98(4): 912-917.

51. Summer ME, Stewart BA (1992) Soil crusting. Chemical and Physical Processes. Advances in Soil Science. Lewis Publishers, CRC Press Inc. Boca Raton, Florida, USA, pp 372.

52. Haberhauer G, Rafferty B, Strebl F, Gerzabek MH (1998) Comparison of the composition of forest soil litter derived from three different sites at various decomposition stages using FTIR spectroscopy. Geoderma 83(4): 331-342.
53. Le Bissonnais Y, Arrouays D (1997) Aggregate stability and assessment of soil crust stability and erodibility: II. Application to humic loamy soils with various organic contents. Eur J Soil Sci 48(1): 39-48.

54. Bristow K, Campbell G, Papendick R, Elliot L (1986) Simulation of heat and moisture transfer through a surface residue-soil system. Agricultural and Forestry Meteorology 36(3): 193-214.

55. Bussière F, Cellier P (1994) Modification of the soil temperature and water content regimes by crop residue mulch: experiment and modeling. Agricultural and Meteorology 68(1-2): 1-28.

56. Dahiya R, Malik RS, Jhorar BS (2003) Effect of sugarcane trash and enriched sugarcane trash mulches on ratoon cane yield and soil properties. Journal of Indian Society 51(4): 504-508.

57. Larson WE, Holt RF, Carlson CW (1978) Residues for soil conservation In Oschwald WR Ed Crop Residue Management Systems. ASA Spec Pub 31: 1-15.

58. Mannering JV, Mayer LD (1963) The effects of various rates of surface mulch on infiltration and erosion. Soil Sci Soc Am Proc 27(1): 84-86.

59. Greenland DJ (1975) Bringing the green revolution to the shifting cultivator Science 190: 841-844.

60. Scopel E, Da Silva FAM, Corbeels M, Affholder F, Maraux F (2004) Modeling crop residue mulching effects on water use and production of maize under semi arid and humid tropical conditions. Agronomie 24(6-7): 383-395.

61. Kamidi M, Gitari F, Osore P, Cheruiyot D, Okumu M, et al. (2000) Effect of green manure legumes on the yield of maize and beans in Matunda farm, Tranzoia District. In: Legume Research Network Project Newsletter 4: 2-5.

62. Gitari JN (2011) Determination of factors influencing the efficiency of legume green manures for maize production in Embu, Kenya.

63. Gachene CKK, Makau M, Haru R, Mureithi JG (2000) Soil moisture extraction by different legume crops. Participatory Technology Development for Soil Management A special publication of the Soil Management and Legume Research Network Projects pp. 133-143.

64. Bi vision (2009) Green Manure.

65. Rutunga V, Karanja N, Gachene CKK, Palm CA (1999) Biomass production and nutrient accumulation by Tephrosia vogelii (Hemsley) A Gray and Tithonia diversifolia Hook $\mathrm{F}$ fallows during six month growth period at Maseno, Western Kenya. Agron Soc Environ 3(4): 237-346.

66. Jama B, Eyasu E, Magosti K (2006) Role of agro forestry in improving food security and natural resource management in the dry lands: a regional overview. Journal of the Dry lands 1(2): 206-211.

67. Eyasu E (2002) Farmers perceptions of soil fertility change and management. SOS Sahel and ISD, Addis Ababa, Ethiopia.

68. Jiru D (1989) Evaluation of crop yield under Acacia albida shade and alley cropping in semiarid farms. In: Proceedings of IAR/ICRAF National Agroforestry Workshop, Institute of Agricultural Research, Addis Ababa, Ethiopia, pp. 33-38.

69. EARO (2000) Forestry research strategic plan. Ethiopian Agricultural Research Organization, Addis Ababa.

70. Sanchez P, Jama B (2000) Soil fertility replenishment takes off in east and Southern Africa. International Symposium on balanced nutrient management systems in sandy loam soils in Georgia, USA. Soil and Tillage Research 63: 167-179.

71. Kwesiga F, Chisuma M (1992) Ethnobotanical survey in Eastern province of Zambia. AFRENA Report no 49 ICRAF, Nairobi, Kenya. 
72. Sanchez PA, Shepherd KD, Soule SJ, Place FM, Buresh RJ, et al. (1997) Soil fertility replenishment in Africa: an investment in natural resource capital. Replenishment soil fertility in Africa SSSA Spec Publ, Madison pp. 1-46.

73. ICRAF (2003) Improved fallows for Western Kenya. An extension guideline. World Agro forestry Center pp. 15-38.

74. WOCAT (2007) Where the land is greener. Case studies and analysis of soil and water conservation initiatives worldwide. Editors HP Liniger, W Critchley. CTA, FAO, UNEP and CDE, University of Bern, Switzerland.

75. Gichuki FN (1992) Indigenous land husbandry practices. Oversees Division Report. Silsoe Research Institute, Silsoe, Bedford, UK.

76. DAREP (1994) Informal diagnostic survey of Tharaka Nithi. Dryland Applied Research and Extension project. KARI, Regional Research Centre, Embu, Kenya.

77. Okoba B, Tomlow S, Mugo C (1998) Evaluation of indigenous soil and water conservation technologies for runoff and soil loss control in semi arid Mbeere District, Kenya. In Modern Methods from traditional soil and water conservation technologies. Proceedings of workshop, Uganda.

78. Lal R (1976) Soil erosion problems on an Alfisol in Western Nigeria and their control. In IITA Monograph No 1 Ibadan, Nigeria.

79. Lal R, De Vleeschauwer D, Mlafa NR (1980) Changes in properties of newly cleared tropical Alfisol as affected by mulching. Soil Sci Soc Am J 44: 827-833.

80. FAO (1999) Uganda Soil Fertility Initiative: Concept Paper. Investment Centre Division, FAO/World Bank Cooperative Program FAO, Rome, Italy.

81. ICRAF (1997) Using the wild sunflower, tithonia, in Kenya for soil fertility and crop yield improvement. Nairobi, Kenya, pp. 1-11.

82. Liniger HP (1988) Water conservation for rain fed farming in the semi arid foothills west and northwest of Mt Kenya: consequences for soil productivity. In: Messerli B, Hurni H Ed African Mountains and Highlands Problems and Perspectives. Walsworth Press Co, Marceline, Missouri 8(2/3): 187-203.

83. Mwangi E, Swallow B (2008) Prosopis juliflora invasion and rural livelihoods in Lake Baringo area of Kenya. Conservat 2008 online serial, Available from: area of Kenya 6(2): 130-140.

84. Hess T, Stephens W (1998) The role modelling in renewable natural resources systems research. In RB Mathews and W Stephens: Crop Simulation Models (eds). Institute of water and Environment Cranifield University for ODA, CAB publishing, Silsoe, England.

85. Kiplangat R, Karuku GN, D Mbui, I Michira, Njomo N (2018) Formulation of Slow Release Fertilizer (cellulose-g-poly(acrylamide)/HA/ SolubleFertilizer) Composite Using Biodegradable Superabsorbent Polymer.

86. Obare L, Wangwe JB (2016) Underlying Causes of Deforestation. World Rainforest Movement.

87. Daily Nation (2018) Pay cut: Police in mass exit threat.

88. Greenhouse Gas Bulletin (2017) Greenhouse gas concentrations surge to new record.

89. Ruhiu JM (2000) Environment and Resource Management in District Planning. Case Study of Ol Bolossat, KWS Nyeri.
90. The Gurdian (2015) Earth's climate entering new permanent reality' as $\mathrm{CO} 2$ hits new high. Accessed on January 26, 2018.

91. Stocking M, Peake L (1985) Erosion-induced Loss in Soil Productivity: Trends in Research and International Cooperation. Food and Agriculture Organization, Rome, Italy.

92. Central Intelligence Agency (2012) The World Fact book. Retrieved $23^{\text {rd }}$ February 2018.

93. Lal R (1995) Tillage systems in the tropics; management options and sustainability implications. In: FAO Soils Bulletin No 71. FAO, Rome, Italy, pp. 206.

94. John N Landers (2000) Zero tillage development in tropical Brazil - the story of a successful NGO activity.

95. Gachene CKK, Palm CA, Mureithi JG (1999) Legume cover crops for soil fertility improvement in Eastern Africa region. Report of an AHI workshop TSBF, Nairobi, Kenya, 19(1): 49-62.

96. Government of Kenya (2009a) Rehabilitation of the Mau Forest Ecosystem. A Project Concept prepared by the Interim Coordinating Secretariat. Office of the Prime Minister, Kenya.

97. http://povertyenvironment.net.

98. http://siteresources.worldbank.org/KENYAEXTN/Resources/ERS. pdf.

99. http://www.agriculturesnetwork.org/magazines/east-africa/62trees-farming/mau-forest-degradation. Retrieved on 24th August, 2016. Degradation of Mau forests threatens agriculture and Kenya's economy.

100. http://www.agriculturesnetwork.org/magazines/east-africa/62trees-farming/mau-forest-degradation\#sthash.jcM9RLhc.dpuf

101. https://www.makueni.go.ke/makueni-fruit-processing-plant-opened

102. https://www.theguardian.com/environment/2016/sep/28/theworld-passes-400ppm-carbon-dioxide-threshold-permanently.

103. Kinyali SM, Karuku GN (1992) Effects of soil, vegetation and land use on infiltration in two semi-arid sub-locations (Sibilo and Loruk) in Baringo District. National Capacity Building for Child Survival and Development Workshop (UNICEF), India.

104. Martens DA, Frankenberger WT (1992) Modification of infiltrations rates in organic amended irrigated soil. Agron J 84(4): 707-717.

105. Otieno AO, Karuku GN, Raunde JM, Koech O (2017) Effectiveness of the Horizontal, Vertical and Hybrid Sub surface flow constructed wetland systems in polishing Municipal Watse water. Environmental Management and Sustainable Development 6(2).

106. Snapp S, Swinton SS, Labarta R, Mutch D, Black JR, et al. (2005) Evaluating cover crops for benefits, costs and performance within cropping system niches. Agron. J 97(1): 322-332.

107. Gurtner M, Liniger H, Studer RM, Hauert C (2011) Sustainable Land Management in Practice. Guidelines and Best Practices for SubSaharan Africa FAO, Rome, Italy.

108. WOCAT (2011) World Overview of Conservation Approaches and Technologies. 


\section{(C) (1) \\ This work is licensed under Creative \\ Commons Attribution 4.0 License}

To Submit Your Article Click Here: Submit Article

DOI: $10.32474 /$ CIACR.2018.02.000148

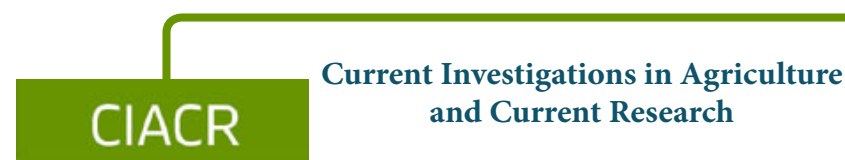

\section{Assets of Publishing with us}

- Global archiving of articles

- Immediate, unrestricted online access

- Rigorous Peer Review Process

- Authors Retain Copyrights

- Unique DOI for all articles 